\title{
May the Force Be with You (Or Not): The Immune System under Microgravity
}

\author{
Mei ElGindi ${ }^{1}$, Jiranuwat Sapudom ${ }^{1}{ }^{\mathbb{D}}$, Ibrahim Hamed Ibrahim ${ }^{1}$, Mohamed Al-Sayegh ${ }^{2} \mathbb{D}$, Weiqiang Chen ${ }^{3,4}$, \\ Anna Garcia-Sabaté 1,*(D) and Jeremy C. M. Teo 1,3,4,*(D) \\ 1 Laboratory for Immuno Bioengineering Research and Applications, Division of Engineering, New York \\ University Abu Dhabi, Abu Dhabi P.O. Box 129188, United Arab Emirates; me95@nyu.edu (M.E.); \\ jiranuwat.sapudom@nyu.edu (J.S.); ihi2005@nyu.edu (I.H.I.) \\ 2 Biology Division, New York University Abu Dhabi, Abu Dhabi P.O. Box 129188, United Arab Emirates; \\ ma3803@nyu.edu \\ 3 Department of Mechanical and Aerospace Engineering, New York University, Brooklyn, NY 11201, USA; \\ wchen@nyu.edu \\ 4 Department of Biomedical Engineering, New York University, Brooklyn, NY 11201, USA \\ * Correspondence: anna.sabate@nyu.edu (A.G.-S.); jeremy.teo@nyu.edu (J.C.M.T.); \\ Tel.: +971-2-6286689 (J.C.M.T.)
}

Citation: ElGindi, M.; Sapudom, J.; Ibrahim, I.H.; Al-Sayegh, M.; Chen, W.; Garcia-Sabaté, A.; Teo, J.C.M. May the Force Be with You (Or Not): The Immune System under Microgravity. Cells 2021, 10, 1941. https://doi.org/ 10.3390/cells10081941

Academic Editor: Javier Conde Aranda

Received: 6 July 2021

Accepted: 29 July 2021

Published: 30 July 2021

Publisher's Note: MDPI stays neutral with regard to jurisdictional claims in published maps and institutional affiliations.

Copyright: (C) 2021 by the authors Licensee MDPI, Basel, Switzerland. This article is an open access article distributed under the terms and conditions of the Creative Commons Attribution (CC BY) license (https:// creativecommons.org/licenses/by/ $4.0 /)$.

\begin{abstract}
All terrestrial organisms have evolved and adapted to thrive under Earth's gravitational force. Due to the increase of crewed space flights in recent years, it is vital to understand how the lack of gravitational forces affects organisms. It is known that astronauts who have been exposed to microgravity suffer from an array of pathological conditions including an impaired immune system, which is one of the most negatively affected by microgravity. However, at the cellular level a gap in knowledge exists, limiting our ability to understand immune impairment in space. This review highlights the most significant work done over the past 10 years detailing the effects of microgravity on cellular aspects of the immune system.
\end{abstract}

Keywords: immune cells; immunology; microgravity; space research; space biology; mechanotransduction

\section{Introduction}

Gravitational force plays an important role in developing the functions and characteristics of all terrestrial organisms. Understanding the effects of gravity on organisms is vital if human space exploration and future colonization are to expand beyond low Earth orbit, which will greatly increase exposure time to microgravity conditions $\left(\times 10^{-6} \mathrm{~g}\right)$, as well as other gravity levels such as the Moon's ( $0.16 \mathrm{~g})$ or Mars' $(0.37 \mathrm{~g})$ gravity. It has been known for decades that lack of these gravitational forces has detrimental physiological effects on the human body. Astronauts who are exposed to microgravity for prolonged periods of time have been found to suffer from decreased neurological function, bone density decline, atrophied muscles, and significantly compromised immune systems upon their return to Earth [1-7]. In terms of bone health, studies showed that astronauts could lose up to $1.5 \%$ of their bone mass every month they spend in space [2,8-14]. Cancer is also a major risk for astronauts due to the changes in gene expression caused by concomitant exposure to radiation as well as the varying gravitational forces [15-17]. Research on the brain shows that astronauts are at greater risk of developing neurological problems such as increased intracranial pressure, visual impairments, and spaceflight-associated neuro-ocular syndrome [15,18-20].

One of the greatest physiological impacts that long term exposure to microgravity has is on the immune system. It is known that immune cell function, morphology, and differentiation are impaired in the absence of gravity [5,6,21-25]. Studies dating back nearly fifty years showed that up to $50 \%$ of astronauts returning from space since the Apollo missions have a compromised immune system and are prone to bacterial and viral 
infections shortly after returning to earth [26]. As the duration of crewed space missions extends, it is becoming increasingly important to understand the role that gravity plays on the immune system, to ensure the well-being of astronauts for the success of these missions. Findings in this field will not only benefit astronauts, but they can also provide a better understanding on the deterioration of the immune system due to aging back on Earth since age-related processes have been reported to be accelerated in microgravity $[27,28]$.

This review will provide a brief overview of the existing microgravity platforms and then highlight the most prominent studies in the past decade to understand the effects of gravity on the immune system. These studies are important to help understand the impact of gravitational forces on the cellular functions and developmental mechanics of immune cells. This review will also provide insight into the aspects of the immune system in microgravity that have yet to be addressed.

\section{Real and Simulated Microgravity Platforms}

Several platforms to obtain microgravity are available, each having different magnitudes and time duration of applied microgravity, and complexity of experimental implementation. We will distinguish between platforms to obtain real microgravity, whether it is on ground or in orbit, and simulated microgravity, which is obtained by leveraging the delay of biological organisms in sensing gravity (Figure 1). When choosing a microgravity platform for any experiment, the time-scale of the experiment is a critical aspect to take into consideration, and biological processes can generally span from a few minutes to several weeks [29].

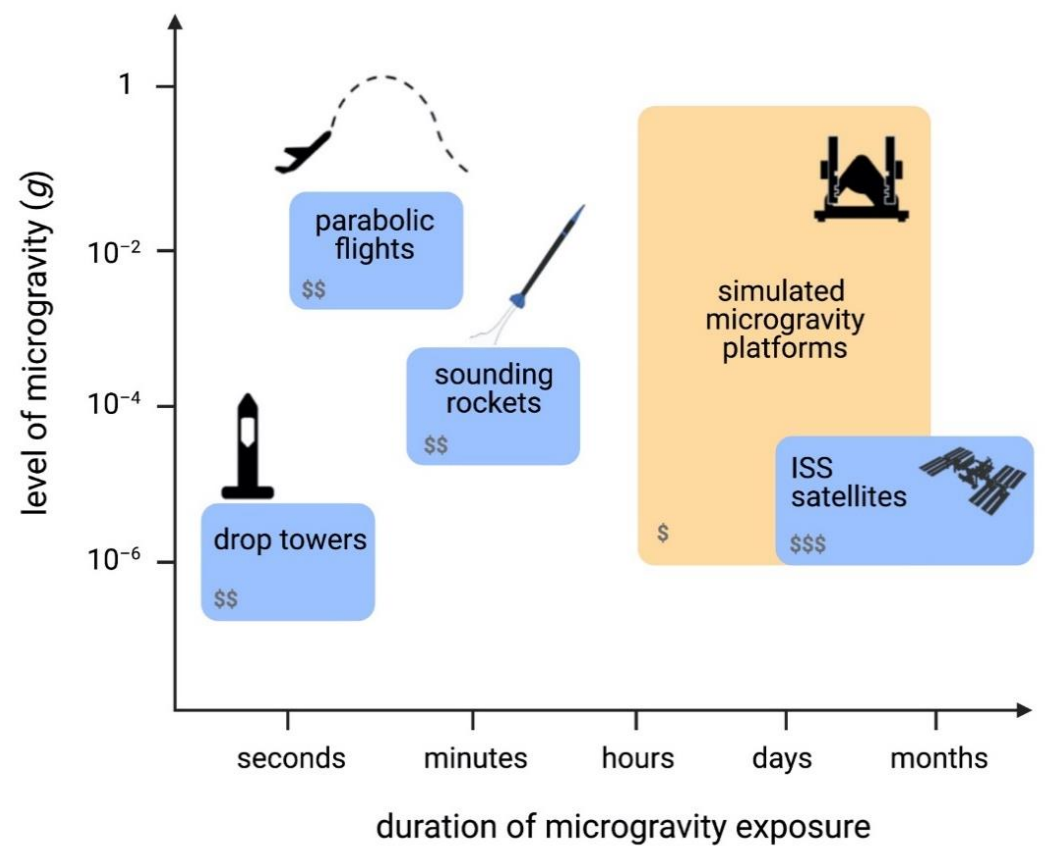

Figure 1. An overview of microgravity platforms. Overview of real (blue) and simulated (yellow) microgravity platforms in terms of duration of microgravity exposure and level of microgravity reached compared to Earth $\mathrm{g}$ (where $\mathrm{g}=9.81 \mathrm{~m} / \mathrm{s}^{2}$ ). Number of $\$$ represents relative cost of running experiments on each platform.

Real microgravity platforms include parabolic flights, which alternate between microgravity and hypergravity ( $2 \mathrm{~g})$ during each parabola [30]. This platform can provide about $20 \mathrm{~s}$ of microgravity conditions per parabola with up to about 30 parabolas per flight, and a microgravity level of $10^{-2} \mathrm{~g}$ (where $\mathrm{g}=9.81 \mathrm{~m} / \mathrm{s}^{2}$ ) [30]. While parabolic flights are a suitable platform for certain aspects of human physiology research due to their large volume, the short intervals of microgravity make them less than ideal for biological experiments that require longer periods of microgravity exposure for measurable results. 
A second platform to study real microgravity is the drop tower. Drop towers can provide very good quality of microgravity $\left(10^{-6} \mathrm{~g}\right)$ at the expense of experimentation time, which is extremely short, ranging from 2.2 to $9.3 \mathrm{~s}$. Sounding rockets, also referred to as suborbital ballistic rockets, can offer 5 to $15 \mathrm{~min}$ of microgravity at levels no higher than $10^{-4} \mathrm{~g}$ [30]. However, they commonly have very limited payload space available, making experimental design very complex, and duration is unsuitable for longer in vitro or in vivo experiments. Moreover, the high levels of hypergravity during launch and re-entry, as well as high spin rates of suborbital rockets, can have negative impacts on the samples [31].

Finally, orbital platforms, from satellites to the International Space Station (ISS), can also provide real microgravity and they can offer long duration at microgravity levels of $10^{-6} \mathrm{~g}$ [30]. Although it is possible for astronauts to have (limited) interaction for experiments on the ISS, it is strongly desirable in both platforms to have a high degree of automation, which will increase the complexity of experimental setups. Access to these platforms is usually costly, and they require very long experimental planning, an iterative development cycle, and lengthy integration times. In recent years, access to space using CubeSats (small satellites) has become more affordable, making CubeSats a potentially suitable platform for biology experiments. However, their size is a limiting factor, posing technical challenges demanding the miniaturizing of common processes required for benchtop biology experiments (e.g., media exchanges, freezing, etc.) and equipment (e.g., brightfield and fluorescence microscopes, flow cytometers, etc.), whilst needing full automation of experiments.

Simulated microgravity can be achieved through a number of platforms that rely on the delay of organisms to sense gravity, as well as their time of sedimentation. By means of rotation under different conditions, they average the vector of gravity to zero over a cycle, making the samples perceive an environment of microgravity. In all cases, the samples must be as close to the center of rotation as possible to prevent any undesired fluid dynamics due to centrifugal forces [32], which need to be taken into consideration during data analysis. These platforms can provide valuable data and are attractive to use as they allow extended experimental time at low cost. Ultimately, they are not a substitute for real microgravity, and results should be further validated in any of the real microgravity platforms [33]. Simulated microgravity is extremely attractive for optimizing microgravityfocused experimental conditions as a first pass prior to real microgravity. The systems in this category include 2D and 3D clinostats, the Rotating Wall Vessel (RWV), also known as the Rotary Cell Culture System (RCCS), and the Random Positioning Machine (RPM) (Figure 1). Clinostats rotate at constant speed either around one axis (2D) or on two axes (3D). RWVs use faster rotation speeds to compensate for sample sedimentation, and thus they are more suitable for suspension cells. However, adherent cells have also been studied before on this platform by culturing them on beads [34]. The RPM rotates on two axes, similarly to the 3D clinostat. However, in this case the two independent frames rotate at different speeds and directions, whereas the 3D clinostat moves at a constant speed in a constant direction.

\section{Immune Cells and Microgravity}

The immune system is an expansive and complex network of cells that protects our body against infection. Here, we provide a brief overview of the immune system as detailed reviews of the immune system are already in published work [35-38] and constantly updated. The human immune system is divided into two parts: the innate immune system and the adaptive immune system (Figure 2). These two systems are highly interconnected and will not serve their complete functions to safeguard our bodies without one another. Microgravity is known to have effects on both parts of the immune system [6,15,39]. In this section, we will discuss the effects of microgravity on the innate immune cells that are involved in phagocytosis of invading pathogens, antigen presentation, and cytokine production as well as the cells of the adaptive immune system. 


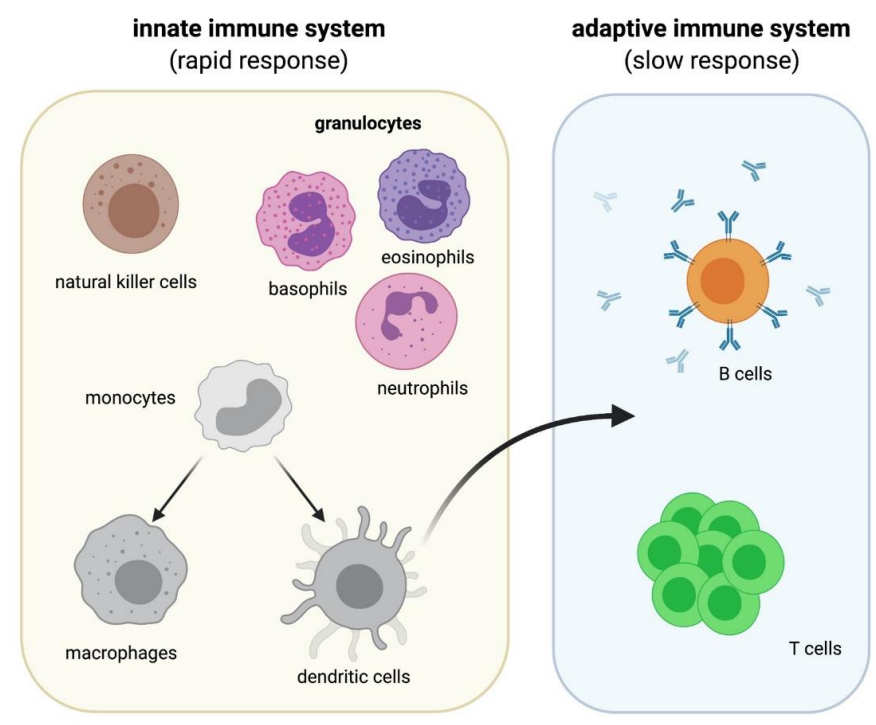

Figure 2. Overview of immune cells in the innate and adaptive immune systems. The schematic provides an overview of the two arms of the immune system: the innate immune system and the adaptive immune system. The innate immune system consists of granulocytes (basophils, neutrophils, and eosinophils), natural killer cells, monocytes, macrophages, and dendritic cells. The adaptive immune system consists of $\mathrm{T}$ cells and B cells with dendritic cells being the main bridge between the two systems.

\subsection{Microgravity Studies on Cells of the Innate Immune System}

The innate immune system is the first line of defense against pathogens. It is made up of granulocytes, natural killer (NK) cells, monocytes, macrophages, and dendritic cells (DCs) (Figure 2). Neutrophils, basophils, and eosinophils are all considered granulocytes; neutrophils are the most abundant granulocyte in the immune system. They are an essential part of the innate immune system and work primarily by phagocytizing pathogens in the blood and tissue. NK cells are a critical subset of the innate immune system and are involved in killing virus infected cells and also react to curb tumor formation. During inflammation, blood borne monocytes are recruited to sites of inflammation and can differentiate into DCs and macrophages. The dysregulation of either cell type can result in chronic infections, blood disorders, autoimmune disorders, and certain cancers, indicating the important role that they play in the immune system $[40,41]$. DCs are also essential in priming the adaptive immune response which is the second line of defense against infection (Figure 2). Along with the detailed review of each cell type below, briefly summarized observations of the effects of microgravity on the innate immune cells can be found in Table 1.

\subsubsection{Neutrophils}

To date, very little work has been done with regard to the effects of microgravity on neutrophil functions both in vivo and in vitro. The several studies on neutrophils have focused on neutrophil numbers present in blood, with a reported increase in circulating neutrophils in humans returning from spaceflight [42,43]. In line with this, a more recent study using 30 parabolas of parabolic flights, with a duration of $20 \mathrm{~s}$ of microgravity in each, showed that neutrophil levels in human blood are slightly increased, whereas all other immune cell subsets, such as T cells and B cells, decreased [44]. Similarly, an increase in neutrophils and neutrophil to lymphocyte ratio (NLR) has been reported in humans during a 180 day spaceflight as well as in human PBMCs cultured for $20 \mathrm{~h}$ on an RWV, at 20 revolutions per minute (rpm), indicating that NLR could be used as a potential biomarker to monitor in flight health [45]. Alternatively, a spaceflight (up to 15 days) study found no change in overall neutrophil levels in sampled human blood before and after flight [46]. Although most studies point towards increased neutrophil levels under 
microgravity, discrepancies in results could be due to specific characteristics of spaceflight (such as duration) or variability of donors.

\subsubsection{Natural Killer (NK) Cells}

The effects of simulated microgravity on primary human NK cells have been studied by means of RWV. The research project investigated several characteristic attributes such as receptor expression and cytokine secretion. The authors found that there was a decrease in NK cell cytotoxicity after $48 \mathrm{~h}$ under simulated microgravity conditions, at $30 \mathrm{rpm}$, that was related to a decrease in associated cytokine production and surface receptor expression [47]. Specifically, NKG2D, an activating receptor found on the surface of NK cells, was found to be significantly reduced. In 2019, a study investigated NK cell function isolated from astronaut peripheral blood that underwent a 6 month mission on the ISS [48]. The results showed impaired NK cell function in terms of cytotoxic activity against leukemia K562 cell line and this impairment was more prominent in astronauts who underwent their first flight compare to experienced astronauts, possibly indicating possible epigenetic adaptation [48]. Another study found that polysaccharides, which are known stimulants of NK cells, were able to restore the expression of NKG2D under RWV simulated microgravity conditions at $30 \mathrm{rpm}$ [49]. These studies suggest that polysaccharides could be useful in promoting a more functional immune response in space.

\subsubsection{Monocytes}

Few studies have addressed the effect of microgravity on monocytes. A study examined the peripheral blood of nine astronauts and found that the total monocyte percentages were unchanged after a 13-16 day spaceflight [50]. However, expression of CD62L and HLA-DR was reduced indicating an impairment in monocyte adhesion to vasculature, tissue migration, and antigen presentation. Following lipopolysaccharide (LPS) stimulation, secreted pro-inflammatory cytokines, namely IL-6, TNF $\alpha$, and IL-10 were reduced, indicative of further impaired monocyte function and inflammatory response during spaceflight [50]. Using parabolic flight and sounding rocket real microgravity conditions, U937 monocytic cells were used to find potential gene targets for standardizing protocols for microgravity studies. Microarray studies identified eight genes (ALB, B4GALT6, GAPDH, $H M B S, Y W H A Z, A B C A 5, A B C A 9$, and $A B C C 1)$ that remained stable during normal and microgravity conditions [51]. This study is significant in providing a step forward in optimizing protocols for microgravity studies. Albeit reserved for U937 cells, discrepancies in results can be avoided by assessing these genes when employing different microgravity platforms and cell handling.

\subsubsection{Macrophages}

Macrophages are differentiated from monocytes and can be activated into different subtypes. The main subtypes are pro-inflammatory (M1) and anti-inflammatory (M2) macrophages. In many in vitro investigations, monocytic cell lines (e.g., THP-1, U937, $\mathrm{J}$-111) are differentiated into uncommitted macrophages using Phorbol 12-myristate 13acetate (PMA) and activated into specific subtypes using interferon-gamma (IFN $\gamma$ ) and LPS for M1, or IL-4 and IL-13 for M2 [52,53]. Notably, PMA also activates other immune cells (e.g., T cells) in a non-specific manner.

Studies have shown that non stimulated U937 cells respond to both parabolic flight and 2D clinostat simulated microgravity at $60 \mathrm{rpm}$ by having increased tyrosine phosphorylation and activated c-jun, whereas PMA stimulated U937 were seen to have the opposite effect, with reduced tyrosine phosphorylation and activation of c-jun [26]. These results indicate that microgravity conditions cause non-specific activation of monocytic U937 cells and that further immune activation via PMA is inhibited under these conditions. Other studies also revealed that PMA stimulated U937 cells had a disorganized cytoskeleton with a significant decrease in actin expression, a cytoskeletal protein, under microgravity conditions. The cells also showed a decreased expression of CD18, CD36, and MHC-II, 
proteins involved in adhesion, scavenging, and antigen presentation, respectively, after 5 days of spaceflight [54]. These data imply an overall decreased function of macrophages under microgravity conditions. Similarly, under real spaceflight conditions of microgravity, J-111 cells were found to have decreased cell motility and a reduction in fluorescence intensity of F-actin in the cells [55]. The cytoskeleton and surface proteins are critical for macrophage morphology, motility towards pathogens, and function and these data indicate that spaceflight and microgravity impair host immune defense.

A study by Paulsen et al. showed that under real microgravity (30 parabolas per parabolic flight and 5 days in spaceflight) and 2D clinostat simulated microgravity (up to 5 days at $60 \mathrm{rpm}$ ) conditions, both PMA differentiated U937 human macrophages and human primary M2 macrophages had an increased expression of intracellular adhesion molecule 1 (ICAM-1) [56]. This study also indicated that murine BV-2 microglial cells had a decrease in ICAM-1 expression under simulated microgravity and undifferentiated U937 cells showed no changes in ICAM-1 levels under any microgravity conditions [56]. The differences observed could be due to species variation or peripheral vs. central nervous system macrophages; however, ICAM-1 could be considered a marker for rapid-response to changes in gravity. Conversely, a study by Tauber et al. reported that human primary M1 macrophages showed a decrease in ICAM-1 expression after 11 days in real microgravity conditions on board the ISS [57]. No structural changes to actin or vimentin were seen during this time and an increase in free fucose was also shown along with a decrease in cell surface bound fucose. These effects could contribute to functional impairment of macrophages and inability to efficiently activate $\mathrm{T}$ cells. The authors also conclude that the lack of significant changes in cell cytoskeleton could reveal a steady state adaptive process to microgravity [57]. Another study showed that human primary M1 macrophages under real microgravity conditions of suborbital ballistic rockets were found to have a significant reduction in cell volume, nuclear volume, and actin cytoskeleton as early as $4 \mathrm{~s}$ in microgravity as opposed to the 11 days seen in the earlier experiment [58]. This showed that there is a rapid response of macrophages to microgravity conditions and that cytoskeleton rearrangement or dysregulation is one of the primary effects of microgravity.

Primary mouse macrophages that were induced with LPS were found to have significantly decreased TNF $\alpha$ levels, but not IL-1 $\beta$ levels after short term culture $(24 \mathrm{~h})$ in an RCCS simulated microgravity system [59]. The molecular studies showed that the intracellular signaling pathway of LPS was not affected by microgravity and that heatshock factor 1 (HSF1), a repressor of the TNF $\alpha$ promoter, was highly activated under these conditions [59]. The results suggest that microgravity affects the signaling pathways of TNF $\alpha$ and IL- $1 \mathrm{~b}$ via different mechanisms. The same RCCS simulated microgravity system, used at $12-25 \mathrm{rpm}$, was determined to induce the overexpression of $\mathrm{C} / \mathrm{EPBb}$, an activator of arginase, in primary mouse macrophage cells [60]. These cells also had increased levels of p38 MAPK, which could lead to the increase in C/EBPb [60]. When these cells were stimulated with LPS, IL-6 levels were increased in simulated microgravity, compared to controls, and IL-12b was down-regulated [60]. Increased arginase levels could have immunosuppressive effects on macrophages and less IL-12b results in dysregulated differentiation of T cells. IL-6 plays several roles in macrophage function, but increased levels could result in impaired neutrophil recruitment to the site of infection. Together these data indicate that microgravity affects macrophage function on a molecular level by disrupting various signaling pathways.

Using a 2D clinostat simulated microgravity system at $60 \mathrm{rpm}$, Brungs et al., have reported that the production of ROS by LPS stimulated NR8383 rat macrophages is diminished under microgravity conditions after $50 \mathrm{~min}$ [61]. This was caused by decreased SYK phosphorylation, which is required for ROS production. If this dysregulation is also present in real microgravity for humans, it could explain astronauts increased susceptibility to infections [62]. Thiel et al. were able to demonstrate the first direct evidence of rapid cellular sensitivity to gravity using NR8383 rat macrophages on the ISS [63]. They found that these cells are able to adapt to microgravity conditions within approximately $30 \mathrm{~s}$. ROS 
oxidative burst levels were found to decrease immediately once microgravity conditions were achieved but quickly re-adapted back when returned to $1 \mathrm{~g}$ conditions [63]. This indicates the potential for macrophages to rapidly adapt to varying gravity conditions. In addition, the NADPH oxidase complex is involved in ROS levels in the cells as well as with the cytoskeleton [64]. This links the microgravity effects on the macrophages back to cytoskeletal disruption discussed earlier in the section.

More recently, gene expression data that showed both real microgravity on 12 day spaceflights and RCCS simulated microgravity ( $24 \mathrm{rpm}$ ) caused a reduction in primary mouse macrophage differentiation and functionality [65]. The data revealed that microgravity decreased the differentiation of hematopoietic progenitor cells into M1 and M2 macrophages [65]. The authors also implicated the RAS/ERK/NFKB pathways as potential targets to combat the detrimental effects microgravity has on M1 macrophages due to the fact that exogenous ERK and NFKB activators were able to counteract the effects of gravity on the macrophages [65]. Wang et al., used RNA-Seq and similarly found that RCCS simulated microgravity $(72 \mathrm{~h}$ at $18 \mathrm{rpm})$ significantly suppresses the production of inflammatory cytokines such as IL- 6 and TNF $\alpha$ as well as the MAPK/ERK pathways in stimulated U937 macrophage cells [66]. Microgravity plays an important role in how macrophages respond to infections as seen by the studies above. Real microgravity and simulated microgravity studies show that it affects multiple pathways and processes within the cells that impairs their ability to provide an adequate immune response.

\subsubsection{Dendritic Cells (DCs)}

Besides macrophages, monocytes also differentiate into dendritic cells during inflammation. Similar to macrophages, monocytic cells lines (e.g., THP-1, U937, J-111) can be differentiated into dendritic cells using IL-4 and granulocyte-macrophage colony-stimulating factor (GM-CSF) [67-69]. They can be further matured using various antigens, including LPS, TNF $\alpha$ as well as viral particles [70,71]. Unlike macrophages, few studies on DCs response to microgravity have been conducted, which is surprising since DCs are the main mediators of the adaptive immune response.

Under simulated microgravity conditions on an RCCS at $16 \mathrm{rpm}$, it was seen that short term culture ( $<72 \mathrm{~h}$ ) of JAWS II DCs (a murine DC cell line) resulted in increased expression of surface markers such as (pSTAT-5, mTOR, GM-CSF, MHCII, CD80 (unstimulated)) and IL-6 production [72]. These changes increased the DCs capability to activate both CD4 and CD8 T cells measured by IL-2 and IFN $\gamma$ production. Prolonged culture (4-14 days) in simulated microgravity, however, reduced these expression markers and the ability to activate $\mathrm{T}$ cells [72]. This provides further insights into how the innate immune system can be compromised by long term spaceflight. RCCS simulated microgravity was also used to determine the effects of development of DCs from human hematopoietic stem cells (HSCs) under microgravity conditions [73]. Low et al. found that plasmacytoid DCs (pDCs) and myeloid DCs (mDCs) (two subtypes of DCs) had greater numbers under normal gravity conditions compared to microgravity after 21 days in culture [73]. These results indicate that spaceflight could impair the development of DCs and greatly suppresses the ability for humans exposed to microgravity to launch an immune response.

\subsection{Microgravity Studies on Cells of the Adaptive Immune System}

The adaptive immune system consists of lymphocytes: T cells and B cells (Figure 2). $T$ cells are essential cells that can develop into several subsets with each having different functions from killing unhealthy host cells to secreting cytokines that provide signals to $B$ cells. The two main subsets of $\mathrm{T}$ cells are CD4+ T cells and CD8+ T cells. After contact with DCs, CD4+ T cells can proliferate and differentiate into different effector subsets of T helper cells (Th1, Th2, Th17, Treg) depending on the cytokines found in their immediate microenvironment, predominantly secreted by the antigen presenting cells (APCs) they are in contact with. Different subtypes of CD4+ T cells are characterized by their cytokine secretion profile and are distinctively involved in protection against 
infection and further regulation of $\mathrm{T}$ cells. CD8+ T cells recognize peptides presented on DCs and destroy undesirable host cells by secretion of Fas ligand (FasL), cytotoxic granules (perforin and granzymes), and cytokines (e.g., TNF $\alpha$ and IFN $\gamma$ ) [74]. Disruption of T cell development and function is one of the primary factors that can lead to autoimmune diseases such as rheumatoid arthritis and type 1 diabetes [75,76]. B cells are responsible for producing antigen specific antibodies to help fight off infections. Dysregulation of $B$ cells leads to a wide variety of autoimmune diseases such as multiple sclerosis and lupus erythematosus [77-79]. Along with the detailed review of each cell type below, briefly summarized observations of the effects of microgravity on the adaptive immune cells can be found in Table 2.

\subsubsection{T Cells}

Relative to other immune cells, the effects of microgravity on $\mathrm{T}$ cell response have been more extensively studied. In vitro experiments to investigate $\mathrm{T}$ cell response use primary cells and cell lines (e.g., human Jurkat T cells and transgenic OT-II mouse cells). Several studies have shown that $\mathrm{T}$ cells repeatedly fail to proliferate or secrete cytokines in response to T Cell Receptor (TCR) agonists, such as concanavalin A (conA) and anti-CD3 antibody, during spaceflight [80-82]. This lack of response was found to be rescued when mitogenic stimulation with PMA was added and was thought to indicate an important role for diacylglycerol (DAG) signaling in T cell response to microgravity [82-84]. In a follow up publication, Simons et al. then concluded that there was no support for this claim and found that there was no impairment of DAG, or further downstream signaling, in CD4+ PBMCs by culture in simulated microgravity using the RWV at $14 \mathrm{rpm}$ [85]. These studies highlight the discrepancies in results when using different microgravity platforms. A 2012 study by Thiel et al. showed that anti-CD3 stimulated, and co-stimulated with anti-CD28 as seen physiologically, human primary and Jurkat $\mathrm{T}$ cells under both 2D clinostat simulated microgravity at $60 \mathrm{rpm}$ and parabolic flight real microgravity conditions had disrupted cell cycle regulatory proteins such as $\mathrm{p} 21^{\text {Waf1/Cip1 }}$, cdc2, and cdc25C [86]. The mRNA expression of cell cycle arrest protein p21 increased 4-fold within $20 \mathrm{~s}$ in anti-CD3/anti-CD28 stimulated primary T cells and 2.9-fold in Jurkat T cells under real microgravity. This phenomenon was able to be reverted by the addition of curcumin, which is a histone acetyltransferase inhibitor. This data indicated that microgravity has a negative effect on the cell cycle process in human T cells. Additionally, it was found that conA and anti-CD28 activated T cells from human PBMCs, in both real microgravity (ISS) and simulated microgravity on the RWV rotating at $14 \mathrm{rpm}$, had significantly downregulated gene expression of Rel/NF-B transcription factors [87]. This leads to a decrease in downstream effectors involved in T cell activation. In addition, CD83 and CD69, early activation signs in $\mathrm{T}$ cells, were found to have almost twofold lower expression in microgravity compared to controls which furthers the point that microgravity has an effect on lymphocyte proliferation [87]. CREB1 and SRF-binding sites also had lower expression in $\mathrm{T}$ cells under microgravity again implying its effects on the T cell activation process [87]. In both non-stimulated and PMA and anti-CD3/anti-CD28 stimulated Jurkat T cells under 2D clinostat rotation at $60 \mathrm{rpm}$ or parabolic flight conditions, there was an increase in the phosphorylation of MAP kinases ERK-1/2, MEK, and p38 which are involved in the signal transduction cascade in T cells [26]. Increased phosphorylation of MAP kinases could lead to a decrease in T cell response upon TCR engagement [26]. In accordance with these data, Tauber et al. found reduced expression of CD3, IL-2 receptor (IL-2R), and p44/42-MAPK-phosphorylation, all indicators of $\mathrm{T}$ cell activation, in primary human conA and anti-CD28 activated T cells undergoing a 6 min microgravity flight [88]. They showed similar results in conA and anti-CD8 activated human T cells using both real microgravity on parabolic flights and simulated microgravity, in 2D clinostat at $60 \mathrm{rpm}$, along with decreased Zap-70 expression, which is critical for T-cell signaling [89]. These data emphasize that $\mathrm{T}$ cell signaling pathways and their functions are negatively affected during exposure to different microgravity platforms. 
Table 1. Overview of the effects of microgravity on cells of the innate immune system.

\begin{tabular}{|c|c|c|c|c|c|}
\hline Cell Type & Gravity Type & Platform & Cell Source & Observation & Ref \\
\hline \multirow{3}{*}{ Neutrophil } & \multirow{2}{*}{ Real } & Parabolic Flight & Human PBMC & Neutrophils are increased while all other immune cell subsets decrease & {$[44]$} \\
\hline & & Spaceflight & Human PBMC & No change in neutrophil numbers before and after flight & [46] \\
\hline & $\begin{array}{c}\text { Real/ } \\
\text { Simulated }\end{array}$ & $\begin{array}{l}\text { Spaceflight/ } \\
\text { RWV }\end{array}$ & Human PBMC & $\begin{array}{c}\text { Increase in neutrophils and neutrophil to lymphocyte ratio which could be used } \\
\text { as a potential biomarker to monitor in flight health }\end{array}$ & {$[45]$} \\
\hline \multirow{3}{*}{ NK } & \multirow[b]{2}{*}{ Simulated } & RWV & Human PBMC & $\begin{array}{c}\text { Decrease in NK cell cytotoxicity related to a decrease in associated cytokine } \\
\text { production and surface receptor expression }\end{array}$ & [47] \\
\hline & & RWV & Human PBMC & $\begin{array}{l}\text { NKG2D was found to be significantly reduced on the surface of NK cells and } \\
\text { rescued with the addition of polysaccharides }\end{array}$ & [49] \\
\hline & Real & ISS & Human PBMC & $\begin{array}{c}\text { Impaired NK cell function in terms of cytotoxic activity against leukemia K562 } \\
\text { cell line }\end{array}$ & {$[48]$} \\
\hline \multirow[b]{2}{*}{ Monocytes } & \multirow[b]{2}{*}{ Real } & Spaceflight & Human PBMC & Total monocyte percentages were unchanged after a 13-16-day spaceflight & [50] \\
\hline & & $\begin{array}{l}\text { Parabolic Flight and } \\
\text { Sounding Rocket }\end{array}$ & U937 & $\begin{array}{c}\text { Microarray studies identified eight genes that remained stable during normal and } \\
\text { microgravity conditions }\end{array}$ & [51] \\
\hline \multirow{5}{*}{ Macrophages } & \multirow{3}{*}{ Real } & Spaceflight & $\mathrm{J}-111$ & J-111 cells were found to have decreased cell motility and a reduction of F-actin & {$[55]$} \\
\hline & & Spaceflight & U937 & $\begin{array}{l}\text { PMA stimulated U937 cells had a disorganized cytoskeleton and decreased } \\
\text { expression of CD18, CD36, and MHC-II }\end{array}$ & [54] \\
\hline & & Sounding Rocket & Human Primary M1 & $\begin{array}{l}\text { Human primary M1 macrophages were found to have a significant reduction in } \\
\text { cell volume, nuclear volume, and actin cytoskeleton as early as } 4 \mathrm{~s} \text { in microgravity }\end{array}$ & [56] \\
\hline & \multirow{2}{*}{$\begin{array}{l}\text { Real/ } \\
\text { Simulated }\end{array}$} & $\begin{array}{l}\text { Parabolic Flight/ } \\
\text { 2D Clinostat }\end{array}$ & U937 & $\begin{array}{l}\text { Microgravity conditions cause non-specific activation of U937 cells and PMA } \\
\text { stimulated U937 cells are inhibited under these conditions }\end{array}$ & [26] \\
\hline & & $\begin{array}{c}\text { Parabolic } \\
\text { Flight/Spaceflight/2D } \\
\text { Clinostat }\end{array}$ & $\begin{array}{c}\text { U937/ } \\
\text { Human Primary M2 }\end{array}$ & $\begin{array}{l}\text { U937 human macrophages and human primary M2 macrophages had an } \\
\text { increased expression of ICAM-1 }\end{array}$ & {$[54]$} \\
\hline \multirow{2}{*}{ DCs } & \multirow{2}{*}{ Simulated } & RCCS & Human PBMC & $\begin{array}{l}\text { pDC and mDC number are decreased under microgravity indicating that } \\
\text { spaceflight could impair the development of these cells }\end{array}$ & [73] \\
\hline & & RCCS & JAWS II DC & $\begin{array}{c}\text { Prolonged culture of DCs in simulated microgravity reduced surface expression } \\
\text { markers and the ability to activate T cells }\end{array}$ & [72] \\
\hline
\end{tabular}


In addition to microgravity playing a role in $\mathrm{T}$ cells function, time of exposure to microgravity has also been implicated in how $\mathrm{T}$ cells are affected. Luo et al. have shown that $\mathrm{T}$ cells isolated from mouse spleens that underwent differential time exposure to rotary bioreactor simulated microgravity, at $10 \mathrm{rpm}$, have different responses to conA stimulation [90]. T-cell activation markers such as CD25, CD69, and inflammatory cytokines (IL-2 and IFN $\gamma$ ) were all decreased in a time dependent manner from 24 to $72 \mathrm{~h}$ with conA stimulation under simulated microgravity [90]. It was also seen that CD4+ T cells were more susceptible to simulated microgravity effects of decreased proliferation than CD8+ $\mathrm{T}$ cells [90]. Decreased proliferation of CD4+ $\mathrm{T}$ cells results in less functional subsets and cytokine production and will weaken immune response against infections. Due to the different roles that $\mathrm{CD} 4+$ and $\mathrm{CD} 8+\mathrm{T}$ cells play in the immune system. This data provides further insight into functional differences created by microgravity exposure on the cell subtypes.

Gene expression studies are important for understanding the network and correlation between genes that are affected by changes in environment. One of the first studies that showed that miRNA expression was altered during spaceflight on the ISS indicated that gene expression of miR-21, which is involved in cell cycle progression and proliferation, was suppressed in conA and anti-CD28 stimulated primary human T cells [91,92]. Microarray analysis also showed that 85 genes, several of which are targets of and regulated by miR-21, were significantly suppressed in these cells [92]. Showing that miRNA is also altered during spaceflight suggests that gravity does not only have an effect on $\mathrm{T}$ cell activation by suppressing transcription factors, but also by blocking noncoding RNA. Thiel et al. used RNA-Seq and found that a greater number of genes were upregulated than down-regulated in non-activated Jurkat T cells [93]. Additionally, genes were upregulated after only $20 \mathrm{~s}$ of microgravity under parabolic spaceflight, indicating that human cells are highly dynamic in their reaction to new gravitational environments [93]. On the other hand, they also performed a $5 \mathrm{~min}$ suborbital ballistic rocket experiment which revealed more genes that were downregulated than upregulated. There were more differentially expressed genes in the $5 \mathrm{~min}$ suborbital ballistic rocket microgravity exposure than in the $20 \mathrm{~s}$ parabolic flight exposure [93]. These differences could be due to the duration of exposure to microgravity, or the gravity level reached by the different platforms (Figure 1). The gene changes were found primarily in regulatory RNA showing that these play an initial role in adaptation to gravity levels [93]. This study also pointed at the importance of having optimized and standardized procedures for studying microgravity effects on cells given the different results that are obtained using different platforms. A similar study showed that there were five genes (ABCA5, GAPDH, HPRT1, PLA2G4A, and RPL13A) that remained unaltered in microgravity conditions during a $20 \mathrm{~s}$ parabolic flight, $5 \mathrm{~min}$ suborbital ballistic rocket flight, and $5 \mathrm{~min} 2 \mathrm{D}$ clinostat simulated microgravity at $60 \mathrm{rpm}$ exposure in non-activated Jurkat $T$ cells [94]. These genes will provide good reference genes for future studies and the authors also suggest that microgravity does not affect gene expression homeostasis more than other environmental stressors such as heat shock, exercise, and exposure to radiation [94]. Recently, it was shown that 11 transcript clusters (TCs) in non-activated Jurkat $\mathrm{T}$ cells were altered during $5 \mathrm{~min}$ under real microgravity conditions on a suborbital ballistic rocket and after 5 min under simulated microgravity on a 2D clinostat rotating at $60 \mathrm{rpm}$ [95]. These common altered TCs were only $1 \%$ of the total TCs found to be changed after suborbital ballistic rocket flight indicating that there should be a more standardized method to study mechanical forces in cell culture [95]. Another gene study showed that primary mouse $\mathrm{T}$ cells activated with anti-CD3 and anti-CD28 in spaceflight for 15 days, or under simulated microgravity on an RWV and RPM for $2.5 \mathrm{~h}$, had suppressed immune regulatory genes compared to controls [96]. All three platforms were compared in relation to qPCR expression of six genes (Il2, Il2r, Ifn, Iigp1, Slamf1, and Tagap) that are expressed early on in T cell activation and they were found to be suppressed under all microgravity platforms [96]. It is important to note that these gene expression studies require further 
investigation into the functional effects to more specifically determine the role microgravity is playing on the cells.

In 2015, a study used OT-II mice, which have transgenic CD4+ T cells specific for the OVA peptide, to show that $\mathrm{T}$ cell tolerance in vivo was suppressed during a 15 day spaceflight [97]. Flight mice showed a 2-fold increase in OT-II cells compared to control as well as a significant increase in proinflammatory cytokines, such as IL-1b and IL-17, release when harvested cells were restimulated with OVA in vitro [98]. Similarly, one of the first studies to look at $\mathrm{T}$ cell and DC interaction in simulated microgravity found that long term culture (5 days) of OT-II T cells in RCCS at $14 \mathrm{rpm}$ results in their resistance to activation by JAWS II DCs [99]. The authors found an increase in CTLA-4, which controls $\mathrm{T}$ cell proliferation, levels on the surface of OT-II T cells, and when blocked, activation was restored indicating that CTLA-4 expression may contribute to this phenomenon [99]. In a more recent study, Bradley et al. showed that murine lymphoma cells were able to produce factors that prevent DCs from activating CD4+ T cells [100]. Under simulated microgravity on an RCCS at $16 \mathrm{rpm}$ for $72 \mathrm{~h}$, the IL-2 production by CD4+ T cells was slightly restored and CD8+ T cell responsiveness was increased compared to controls showing that simulated microgravity could help prevent tumor mediated escape and make the cancer cells more susceptible to T cells [100]. More studies are needed to further understand the effects of microgravity on T cell interactions with DCs and other cells of the immune system since this is a critical in vivo step to mount an adequate immune response.

Non-activated Jurkat cells placed under simulated microgravity conditions in an RPM at $60 \mathrm{deg} / \mathrm{s}$ were found to have decreased $\mathrm{Ca}^{2+}$ and ROS levels compared to $1 \mathrm{~g}$ controls up to $24 \mathrm{~h}$ under these conditions [101]. The results further suggest that by $96 \mathrm{~h}$, these cells adapt to the new environment and return to control levels [101]. In another metabolic study, authors found that although HIF1 $\alpha$ is significantly reduced in non-activated Jurkat cells during the hypergravity phase of parabolic flights, the levels of HIF1 $\alpha$ remained relatively unchanged during microgravity exposure [102]. This could potentially be due to the short exposure time to microgravity of parabolic flights and the effects of long-term exposure should be further investigated to better understand the metabolic changes of the cells under microgravity.

\subsubsection{B Cells}

A 15 day real spaceflight study showed no changes in B cell levels in the peripheral blood of astronauts [46]. In accordance with this, a 6 month spaceflight study showed no change in overall $B$ cell subset numbers or proportions or in levels of plasma immunoglobulins (Igs) [103]. However, Tascher et al. found a significant reduction in B cells in the spleens of mice 1 week after landing from a 1 month flight in space [104]. These differences could be species related. This decrease of B cells was also seen in a parabolic flight real microgravity setting in human peripheral blood [44]. Microgravity and radiation are two of the main factors that influence astronauts' health while in space. Because these effects are difficult to recreate simultaneously, it is difficult to study them in vivo in real microgravity or in vitro in simulated microgravity. Only one study has demonstrated the effect of microgravity and radiation on B cells. Dang et al. found that simulated microgravity on an RWV decreased ion-radiation generated cell survival and increased apoptosis in human B lymphoblast HMy2.CIR cells [105]. These conditions also increased radiation induced intracellular ROS generation [105]. However, less is known about the extent to which microgravity affects antigen-specific response and antibody production of $\mathrm{B}$ cells. 
Table 2. Overview of the effects of microgravity on cells of the adaptive immune system.

\begin{tabular}{|c|c|c|c|c|c|}
\hline Cell Type & Gravity Type & Platform & Cell Source & Observation & Ref. \\
\hline \multirow{16}{*}{ T cells } & \multirow{4}{*}{ Simulated } & RWV & Human PBMC & Microgravity causes no impairment of DAG, or further downstream signaling, in CD4+ T cells & [85] \\
\hline & & RCCS & Mouse Primary & $\begin{array}{l}\text { CD25, CD69, IL-2 and IFN } \gamma \text { were all decreased in a time dependent manner from } 24 \text { to } 72 \mathrm{~h} \\
\text { under simulated microgravity. CD4+ T cells were more susceptible to simulated microgravity } \\
\text { effects of decreased proliferation than CD } 8+T \text { cells }\end{array}$ & [90] \\
\hline & & RCCS & OT II mice & Long term culture of OT-II T cells results in resistance to activation by JAWS II DCs & [99] \\
\hline & & RPM & Jurkat $\mathrm{T}$ cells & Decreased $\mathrm{Ca}^{2+}$ and ROS levels compared to $1 \mathrm{~g}$ controls & [101] \\
\hline & \multirow{5}{*}{ Real } & Spaceflight & Human PBMC & Reduced expression of CD3, IL-2R and p44/42-MAPK-phosphorylation & [88] \\
\hline & & ISS & Human PBMC & Gene expression of miR-21 was suppressed in conA and anti-CD28 stimulated T cells & [92] \\
\hline & & Spaceflight & OT II mice & $\begin{array}{l}\text { 2-fold increase in OT-II cells in microgravity and an increase in IL-1b and IL-17 release when } \\
\text { the cells were restimulated with OVA in vitro }\end{array}$ & [98] \\
\hline & & $\begin{array}{l}\text { Sounding Rocket/ } \\
\text { Parabolic Flight }\end{array}$ & Jurkat $\mathrm{T}$ cells & Gene changes were found primarily in regulatory RNA & [93] \\
\hline & & Parabolic Flight & Jurkat T cells & Levels of HIF1a remained relatively unchanged during microgravity exposure & [102] \\
\hline & \multirow{7}{*}{$\begin{array}{l}\text { Real/ } \\
\text { Simulated }\end{array}$} & $\begin{array}{l}\text { 2D Clinostat/ } \\
\text { Parabolic Flight }\end{array}$ & Jurkat $\mathrm{T}$ cells & Increase in the phosphorylation of MAP kinases ERK-1/2, MEK, and p38 & [26] \\
\hline & & $\begin{array}{l}\text { 2D Clinostat/ } \\
\text { Parabolic Flight }\end{array}$ & Human PBMC/Jurkat T cells & Microgravity disrupted cell cycle regulatory proteins such as $\mathrm{p} 21^{\text {Waf1/Cip1 }}, \mathrm{cdc} 2$, and $\mathrm{cdc} 25 \mathrm{C}$ & [86] \\
\hline & & $\begin{array}{l}\text { ISS/ } \\
\text { RWV }\end{array}$ & Human PBMC & T cells had significantly downregulated gene expression of Rel/NF-B transcription factors & [87] \\
\hline & & $\begin{array}{c}2 \mathrm{D} / \\
\text { parabolic }\end{array}$ & Human PBMC & Anti-CD28/conA activated T cells had decreased Zap-70 expression & [89] \\
\hline & & $\begin{array}{l}\text { Sounding Rocket/Parabolic } \\
\text { Flight/2D Clinostat }\end{array}$ & Jurkat $\mathrm{T}$ cells & 5 genes remained unaltered in all microgravity conditions & [94] \\
\hline & & $\begin{array}{l}\text { Sounding Rocket/2D } \\
\text { Clinostat }\end{array}$ & Jurkat $\mathrm{T}$ cells & 11 transcript clusters in non-activated Jurkat $\mathrm{T}$ cells were altered & [95] \\
\hline & & Spaceflight/RWV and RPM & Mouse Primary & T cells had suppressed immune regulatory genes compared to controls & [96] \\
\hline \multirow{4}{*}{ B cells } & Simulated & RWV & HMy2.CIR & S decreased ion-radiation induced cell survival and increased apoptosis & [105] \\
\hline & \multirow{3}{*}{ Real } & Parabolic Flight & Human PBMC & A decrease in B cells & {$[44]$} \\
\hline & & Spaceflight & Human PBMC & 15-day spaceflight showed no changes in B cell levels & [46] \\
\hline & & Spaceflight & Mouse Primary & A significant reduction in B cells in the spleens of mice & [104] \\
\hline
\end{tabular}




\section{Future Directions and Discussion}

\subsection{Is There a Link between Microgravity and Mechanotransduction?}

From these reviewed studies, it is apparent that microgravity influences immune cells in a variety of ways. Many of the effects of microgravity could be due to the lack of gravitational force on the cells. In order to understand how microgravity is able to affect cells, it is important to know how cells sense forces acting on them. A process called mechanotransduction allows cells to convert mechanical forces (e.g., from the surrounding extracellular matrix or biomaterials) into biochemical signals that then induce downstream pathways [23]. Briefly, detection of these forces occurs through G-protein coupled receptors (GPCRs), integrins, and mechanosensitive ion channels that then transduce the force into biochemical or electrical signals within cells [106] (Figure 3). The transient receptor potential (TRP) ion channel superfamily and the Piezo ion channel family are two of the most important ion channels in mechanotransduction $[107,108]$. These receptors and channels initiate a variety of signals within the cell affecting molecular pathways and ultimately, gene expression. Comprehensive reviews on mechanotransduction can be found in these cited papers [107-115] (Figure 3). It is reported that gravitational force plays an important role in regulating cell processes and any reduction in this force (for example in the form of microgravity) shifts the balance and homeostasis within cells [22]. Future work should focus more on how mechanotransduction pathways are affected under microgravity conditions. This can be achieved using RNA-Seq and cytoskeleton inhibitors, e.g., cytochalasin $\mathrm{D}$, blebbistatin, and ML-7, to probe whether and which mechanotransduction pathways are involved in cellular sensing of microgravity [116-118].

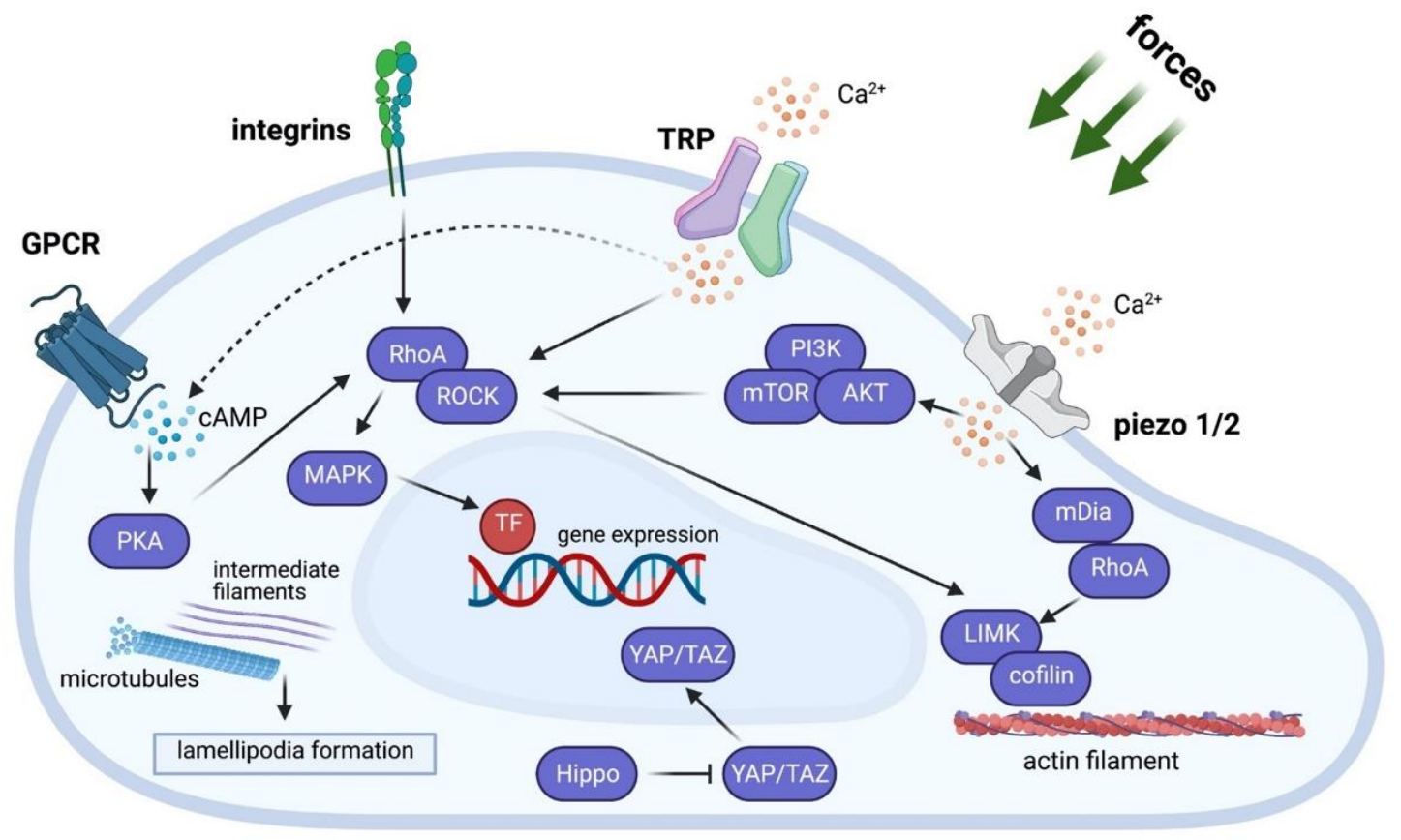

Figure 3. A simplified overview of the mechanotransduction pathways. Illustration depicting the major mechanotransduction pathways that are influenced by force and ultimately affect cell gene expression.

\subsection{Technological Advances for Future Microgravity Research}

The extent by which immune cells have been studied in microgravity revealed differences, at times contradicting, immune signatures at the genetic, protein expression, cytokine secretion, and functional level. This is still the tip of the iceberg and similar levels of research have to be furthered for all the other immune cell types reviewed here, and similarly at the multiculture and organoid levels, to fully comprehend the immune system in microgravity conditions. Although immunological research in microgravity appears 
to be straightforward, there are some limitations of the current techniques and handling to be addressed. Especially, current methods for using simulated microgravity platforms can limit the scope of investigation if large cell culture vessel sizes are used (e.g., T25 and T75 flasks). The large vessels (e.g., cell culture flask) sometimes used in simulated microgravity conditions require high cell numbers and copious volumes of media. Furthermore, the rotation speed of simulated microgravity platforms largely changes between platforms, ranging from a few degrees per second to tens of revolutions per minute (i.e., $>3600 \mathrm{deg} / \mathrm{s}$ ), which might cause slight discrepancies between platforms. As discussed above, many experiments in microgravity research were performed using cell lines rather than primary cells. A need for smaller cell culture vessels is therefore required, especially for the study of non-proliferating primary immune cells. Recently, biocompatible and easy to use microvessels have been developed for use in simulated microgravity allowing for more high throughput studies to be performed (Figure 4A) [119]. Although the advantage of using cell lines avoids genetic variability between donors, they cannot fully represent the biological significance of primary cells (e.g., macrophages from PBMC vs. THP-1). Besides that, contradictory results could be observed for both primary cell and cell lines due to differences in cell differentiation protocols. A standardized differentiation protocol could make the obtained data comparable between research groups. In addition, most of the experiments have addressed the alteration in cellular response in a short period (within several hours). Long term studies (days or weeks) will increase the significance impact and enhance translational possibilities.

\section{A} conventional RPM experiment

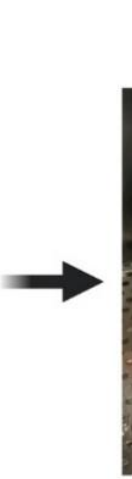
RPM experiment
with microvessel

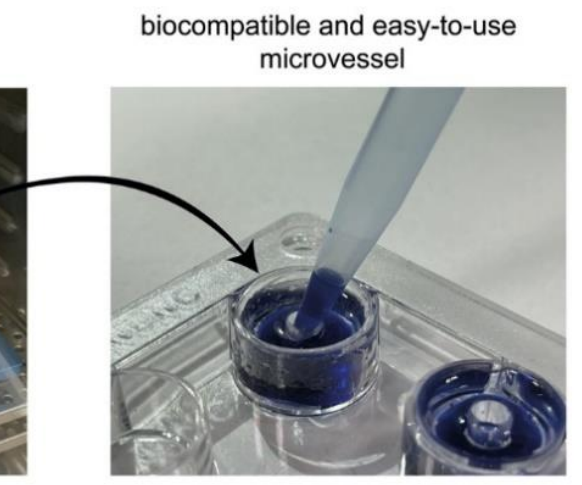

B
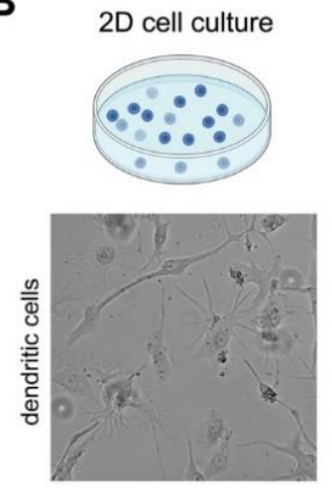

$3 \mathrm{D}$ cell culture
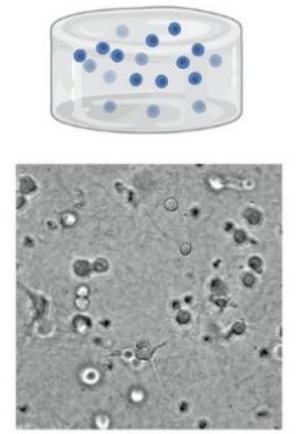

C

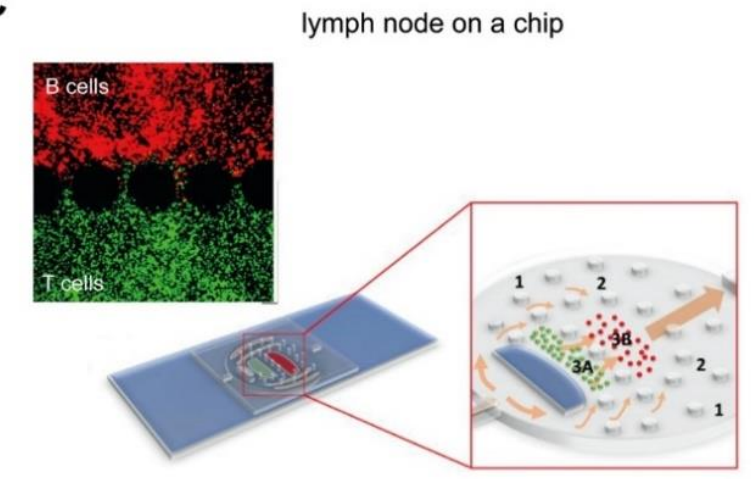

Figure 4. Cell culture techniques for improved physiological relevance in microgravity research. (A) Biocompatible and easy to use microvessels developed for high throughput studies [119]. (B) 2D and 3D biomimetic cell culture model showing more rounded cells in 3D culture compared to 2D [69]. (C) Organ on a chip technology by combining 3D cell culture and microfluidic systems [120].

Growing evidence points towards a key role of the extracellular matrix in the modulation of the potency of immune cells [52,69,121-123]. Traditional 2D cell culture plastics (e.g., microwell plate, Petri dish, and cell culture flask) are unable to resemble the in vivo 
situation [124,125]. The main advantages of 2D tissue plastic cell culture are easier environmental control cell observation, measurement, and eventual manipulation in comparison with 3D cell culture models. As a major consequence non-physiological cell behavior and failure in the translation of cell culture results have been reported [126-130]. To better simulate the in vivo situation, more complex 3D models have been introduced for example using collagen, alginate, or PEG [38,131-134]. The 3D models should span the gap between traditional 2D cell culture plastic and an animal model by mimicking key features of the native microenvironment. The additional dimensionality of 3D culture leads to the differences in cellular responses because of the spatial organization of the cell surface receptors and the physical constraints to cells. As an example, the morphology of dendritic cells is different in 2D culture and 3D culture in collagen matrices [69] (Figure 4B). Although few reports utilized 3D cell culture models to study cells under microgravity [135-137], no work has been done with regard to immune cells in 3D under real microgravity or simulated microgravity. The 3D scaffolds could benefit the study of immune modulation in wound healing and tissue regeneration [138,139], which could be drastically different during spaceflight. Besides 3D cell culture models, microfluidic devices could enhance the understanding of the immune system in microgravity as immune cells are always exposed to shear flow, during inflammation within interstitial tissues or within lymph nodes. As an example, an engineered lymph node on a chip could enable the study of the adaptive immune response during infection or allergy, as well as can be used as a testing platform for drug screening [120,140,141] (Figure 4C). Combining these novel technologies with microgravity platforms could be used to uncover immunotherapy drug targets and provide further insight into disease specific immune responses. Research has shown that microgravity has a positive impact on combating diseases such as cancer by regulating cancer cell proliferating and survival [142-144]. The mechanisms found can be used to benefit cancer treatment on Earth. Microgravity is increasingly being used as a unique platform for assisting in drug discovery and development [145], as well as for implementing personalized medicine treatments [146].

Many key discoveries in cell biology would not have been possible without microscopy. Currently, bright-field microscopy can provide multi-scale spatio-temporal studies of cell migration [147], proliferative behavior [148], and cell mechanics [149]. In particular, single cell mechanics is of interest in modern cell biology and immunology. It allows prediction of pathogen infected cells [150], maturation stage of dendritic cells [151,152], and T cell and antigen-presenting cell interactions $[153,154]$. Cell mechanics has been hypothesized to alter as an adaptation mechanism to microgravity since it might be correlated to cytoskeleton remodeling $[55,56,58]$. Combining the $3 \mathrm{D}$ cell culture models with a live imaging platform in microgravity conditions will allow observation of cells in their native stage with minimal cell manipulation at the single cell level. While microscopy systems are available onboard the ISS, in parabolic flights or suborbital rockets [155], simulated microgravity platforms generally lack this feature. So far, only clinostats rotating around one axis or a specialized custom-made RPM incorporating a digital holographic microscope have cell imaging capabilities [156]. Recently, a microscope has been implemented for use on simulated microgravity platforms [157]. However, there is still room for improvement in terms of automation, resolution of images, and having depth capabilities in imaging 3D culture models.

Overall, the study of immune cells under microgravity conditions has been studied for tens of years. Despite the knowledge that we already have, there is a long way to go before we fully comprehend the dynamic network of the immune system under microgravity. More studies should be done to understand the interactions between cells of the immune system in microgravity and how they are affected as a whole system in vivo. Most importantly, standardized protocols are needed for studying the effects of both real and simulated microgravity. 
Author Contributions: M.E., J.S., and A.G.-S. wrote the paper, illustrated, and put together the tables. I.H.I., M.A.-S., W.C. and J.C.M.T. proofread the manuscript. All authors have read and agreed to the published version of the manuscript.

Funding: This research was funded by New York University Abu Dhabi (NYUAD) Faculty Research Fund (AD266) and NYUAD Research Enhancement Fund (RE267).

Data Availability Statement: Not applicable.

Acknowledgments: The figures were created with BioRender.com.

Conflicts of Interest: The authors declare that there are no competing interests.

\section{References}

1. Van Ombergen, A.; Demertzi, A.; Tomilovskaya, E.; Jeurissen, B.; Sijbers, J.; Kozlovskaya, I.B.; Parizel, P.M.; Van de Heyning, P.H.; Sunaert, S.; Laureys, S.; et al. The effect of spaceflight and microgravity on the human brain. J. Neurol. 2017, 264, 18-22. [CrossRef]

2. Grimm, D.; Grosse, J.; Wehland, M.; Mann, V.; Reseland, J.E.; Sundaresan, A.; Corydon, T.J. The impact of microgravity on bone in humans. Bone 2016, 87, 44-56. [CrossRef]

3. Tanaka, K.; Nishimura, N.; Kawai, Y. Adaptation to microgravity, deconditioning, and countermeasures. J. Physiol. Sci. 2017, 67, 271-281. [CrossRef]

4. White, R.J.; Averner, M. Humans in space. Nature 2001, 409, 1115-1118. [CrossRef] [PubMed]

5. Sonnenfeld, G. The immune system in space and microgravity. Med. Sci. Sport. Exerc. 2002, 34, 2021-2027. [CrossRef] [PubMed]

6. Prasad, B.; Grimm, D.; Strauch, S.M.; Erzinger, G.S.; Corydon, T.J.; Lebert, M.; Magnusson, N.E.; Infanger, M.; Richter, P.; Krüger, M. Influence of Microgravity on Apoptosis in Cells, Tissues, and Other Systems In Vivo and In Vitro. Int. J. Mol. Sci. 2020, 21, 9373. [CrossRef]

7. Garrett-Bakelman, F.E.; Darshi, M.; Green, S.J.; Gur, R.C.; Lin, L.; Macias, B.R.; McKenna, M.J.; Meydan, C.; Mishra, T.; Nasrini, J.; et al. The NASA twins study: A multidimensional analysis of a year-long human spaceflight. Science 2019, 364. [CrossRef]

8. Smith, J.K. Osteoclasts and microgravity. Life 2020, 10, 207. [CrossRef] [PubMed]

9. Ikegame, M.; Hattori, A.; Tabata, M.J.; Kitamura, K.I.; Tabuchi, Y.; Furusawa, Y.; Maruyama, Y.; Yamamoto, T.; Sekiguchi, T.; Matsuoka, R.; et al. Melatonin is a potential drug for the prevention of bone loss during space flight. J. Pineal Res. 2019, 67, e12594. [CrossRef]

10. Wu, C.H.; Ou, C.H.; Yen, I.C.; Lee, S.Y. 4-Acetylantroquinonol B Inhibits Osteoclastogenesis By Inhibiting the Autophagy Pathway in a Simulated Microgravity Model. Int. J. Mol. Sci. 2020, 21, 6971. [CrossRef] [PubMed]

11. Lee, S.J.; Lehar, A.; Meir, J.U.; Koch, C.; Morgan, A.; Warren, L.E.; Rydzik, R.; Youngstrom, D.W.; Chandok, H.; George, J.; et al. Targeting myostatin/activin A protects against skeletal muscle and bone loss during spaceflight. Proc. Natl. Acad. Sci. USA 2020, 117, 23942-23951. [CrossRef]

12. Sotnezova, E.V.; Markina, E.A.; Andreeva, E.R.; Buravkova, L.B. Myeloid Precursors in the Bone Marrow of Mice after a 30-Day Space Mission on a Bion-M1 Biosatellite. Bull. Exp. Biol. Med. 2017, 162, 496-500. [CrossRef]

13. Donaubauer, A.J.; Deloch, L.; Becker, I.; Fietkau, R.; Frey, B.; Gaipl, U.S. The influence of radiation on bone and bone cellsdifferential effects on osteoclasts and osteoblasts. Int. J. Mol. Sci. 2020, 21, 6377. [CrossRef] [PubMed]

14. Zayzafoon, M.; Meyers, V.E.; McDonald, J.M. Microgravity: The immune response and bone. Immunol. Rev. 2005, 208, 267-280. [CrossRef] [PubMed]

15. Patel, Z.S.; Brunstetter, T.J.; Tarver, W.J.; Whitmire, A.M.; Zwart, S.R.; Smith, S.M.; Huff, J.L. Red risks for a journey to the red planet: The highest priority human health risks for a mission to Mars. NPJ Microgravity 2020, 6, 33. [CrossRef] [PubMed]

16. Prasanth, D.; Suresh, S.; Prathivadhi-Bhayankaram, S.; Mimlitz, M.; Zetocha, N.; Lee, B.; Ekpenyong, A. Microgravity modulates effects of chemotherapeutic drugs on cancer cell migration. bioRxiv 2019, 1-11. [CrossRef]

17. Ahn, C.B.; Lee, J.H.; Han, D.G.; Kang, H.W.; Lee, S.H.; Lee, J.I.; Son, K.H.; Lee, J.W. Simulated microgravity with floating environment promotes migration of non-small cell lung cancers. Sci. Rep. 2019, 9, 14553. [CrossRef] [PubMed]

18. Marshall-Goebel, K.; Damani, R.; Bershad, E.M. Brain Physiological Response and Adaptation during Spaceflight. Clin. Neurosurg. 2019, 85, E815-E821. [CrossRef] [PubMed]

19. Overbey, E.G.; Paul, A.M.; da Silveira, W.A.; Tahimic, C.G.T.; Reinsch, S.S.; Szewczyk, N.; Stanbouly, S.; Wang, C.; Galazka, J.M.; Mao, X.W. Mice exposed to combined chronic low-dose irradiation and modeled microgravity develop long-term neurological sequelae. Int. J. Mol. Sci. 2019, 20, 4094. [CrossRef]

20. Khossravi, E.A.; Hargens, A.R. Visual disturbances during prolonged space missions. Curr. Opin. Ophthalmol. 2021, 32, 69-73. [CrossRef]

21. Crucian, B.; Simpson, R.J.; Mehta, S.; Stowe, R.; Chouker, A.; Hwang, S.A.; Actor, J.K.; Salam, A.P.; Pierson, D.; Sams, C. Terrestrial stress analogs for spaceflight associated immune system dysregulation. Brain. Behav. Immun. 2014, 39, 23-32. [CrossRef]

22. Bradbury, P.; Wu, H.; Choi, J.U.; Rowan, A.E.; Zhang, H.; Poole, K.; Lauko, J.; Chou, J. Modeling the Impact of Microgravity at the Cellular Level: Implications for Human Disease. Front. Cell Dev. Biol. 2020, 8, 96. [CrossRef]

23. Lin, X.; Zhang, K.; Wei, D.; Tian, Y.; Gao, Y.; Chen, Z.; Qian, A. The impact of spaceflight and simulated microgravity on cell adhesion. Int. J. Mol. Sci. 2020, 21, 3031. [CrossRef] [PubMed] 
24. Akiyama, T.; Horie, K.; Hinoi, E.; Hiraiwa, M.; Kato, A.; Maekawa, Y.; Takahashi, A.; Furukawa, S. How does spaceflight affect the acquired immune system? Jpn. Microgravity 2020, 6, 1-7. [CrossRef] [PubMed]

25. Smith, J.K. IL-6 and the dysregulation of immune, bone, muscle, and metabolic homeostasis during spaceflight. npj Microgravity 2018, 4, 24. [CrossRef] [PubMed]

26. Paulsen, K.; Thiel, C.; Timm, J.; Schmidt, P.M.; Huber, K.; Tauber, S.; Hemmersbach, R.; Seibt, D.; Kroll, H.; Grote, K.-H.; et al. Microgravity-induced alterations in signal transduction in cells of the immune system. Acta Astronaut. 2010, 67, 1116-1125. [CrossRef]

27. Choukèr, A.; Ullrich, O. The Immune System in Space: Are We Prepared? SpringerBriefs in Space Life Sciences; Springer International Publishing: Cham, Switzerland, 2016; ISBN 978-3-319-41464-5.

28. Shetty, A.K. Introduction. Aging Cell 2004, 3, 331. [CrossRef]

29. Secrier, M.; Schneider, R. Visualizing time-related data in biology, a review. Brief. Bioinform. 2014, 15, 771-782. [CrossRef]

30. Ferranti, F.; Del Bianco, M.; Pacelli, C. Advantages and limitations of current microgravity platforms for space biology research. Appl. Sci. 2021, 11, 68. [CrossRef]

31. Maier, J.A.M.; Cialdai, F.; Monici, M.; Morbidelli, L. The Impact of Microgravity and Hypergravity on Endothelial Cells. Biomed Res. Int. 2015, 2015, 1-13. [CrossRef]

32. Wuest, S.L.; Stern, P.; Casartelli, E.; Egli, M. Fluid Dynamics Appearing during Simulated Microgravity Using Random Positioning Machines. PLoS ONE 2017, 12, e0170826. [CrossRef] [PubMed]

33. Herranz, R.; Anken, R.; Boonstra, J.; Braun, M.; Christianen, P.C.M.; de Geest, M.; Hauslage, J.; Hilbig, R.; Hill, R.J.A.; Lebert, M.; et al. Ground-Based Facilities for Simulation of Microgravity: Organism-Specific Recommendations for Their Use, and Recommended Terminology. Astrobiology 2013, 13, 1-17. [CrossRef] [PubMed]

34. Hammond, T.G.; Hammond, J.M. Optimized suspension culture: The rotating-wall vessel. Am. J. Physiol. Physiol. 2001, 281, F12-F25. [CrossRef] [PubMed]

35. Cyster, J.G.; Allen, C.D.C. B Cell Responses: Cell Interaction Dynamics and Decisions. Cell 2019, 177, 524-540. [CrossRef]

36. Davenport, M.P.; Smith, N.L.; Rudd, B.D. Building a T cell compartment: How immune cell development shapes function. Nat. Rev. Immunol. 2020, 20, 499-506. [CrossRef]

37. Chaplin, D.D. Overview of the immune response. J. Allergy Clin. Immunol. 2010, 125, S345. [CrossRef]

38. Witzel, I.I.; Nasser, R.; Garcia-Sabaté, A.; Sapudom, J.; Ma, C.; Chen, W.; Teo, J.C.M. Deconstructing Immune Microenvironments of Lymphoid Tissues for Reverse Engineering. Adv. Healthc. Mater. 2019, 8, 1801126. [CrossRef]

39. Tavassoli, M. Medical problems of space flight. Am. J. Med. 1986, 81, 850-854. [CrossRef]

40. Shaw, A.C.; Goldstein, D.R.; Montgomery, R.R. Age-dependent dysregulation of innate immunity. Nat. Rev. Immunol. 2013, 13, 875-887. [CrossRef] [PubMed]

41. Frizinsky, S.; Haj-Yahia, S.; MacHnes Maayan, D.; Lifshitz, Y.; Maoz-Segal, R.; Offengenden, I.; Kidon, M.; Agmon-Levin, N. The innate immune perspective of autoimmune and autoinflammatory conditions. Rheumatology 2019, 58, VI1-VI8. [CrossRef]

42. Kaur, I.; Simons, E.R.; Castro, V.A.; Mark Ott, C.; Pierson, D.L. Changes in neutrophil functions in astronauts. Brain. Behav. Immun. 2004, 18, 443-450. [CrossRef] [PubMed]

43. Ichiki, A.T.; Gibson, L.A.; Jago, T.L.; Strickland, K.M.; Johnson, D.L.; Lange, R.D.; Allebban, Z. Effects of spaceflight on rat peripheral blood leukocytes and bone marrow progenitor cells. J. Leukoc. Biol. 1996, 60, 37-43. [CrossRef] [PubMed]

44. Stervbo, U.; Roch, T.; Kornprobst, T.; Sawitzki, B.; Grütz, G.; Wilhelm, A.; Lacombe, F.; Allou, K.; Kaymer, M.; Pacheco, A.; et al. Gravitational stress during parabolic flights reduces the number of circulating innate and adaptive leukocyte subsets in human blood. PLoS ONE 2019, 13, e020627. [CrossRef] [PubMed]

45. Paul, A.M.; Mhatre, S.D.; Cekanaviciute, E.; Schreurs, A.S.; Tahimic, C.G.T.; Globus, R.K.; Anand, S.; Crucian, B.E.; Bhattacharya, S. Neutrophil-to-Lymphocyte Ratio: A Biomarker to Monitor the Immune Status of Astronauts. Front. Immunol. 2020, 11, 1-12. [CrossRef]

46. Cao, D.; Song, J.; Ling, S.; Niu, S.; Lu, L.; Cui, Z.; Li, Y.; Hao, S.; Zhong, G.; Qi, Z.; et al. Hematopoietic stem cells and lineage cells undergo dynamic alterations under microgravity and recovery conditions. FASEB J. 2019, 33, 6904-6918. [CrossRef]

47. Li, Q.; Mei, Q.; Huyan, T.; Xie, L.; Che, S.; Yang, H.; Zhang, M.; Huang, Q. Effects of simulated microgravity on primary human NK cells. Astrobiology 2013, 13, 703-714. [CrossRef]

48. Bigley, A.B.; Agha, N.H.; Baker, F.L.; Spielmann, G.; Kunz, H.E.; Mylabathula, P.L.; Rooney, B.V.; Laughlin, M.S.; Mehta, S.K.; Pierson, D.L.; et al. NK cell function is impaired during long-duration spaceflight. J. Appl. Physiol. 2019, 126, 842-853. [CrossRef]

49. Huyan, T.; Li, Q.; Yang, H.; Jin, M.L.; Zhang, M.J.; Ye, L.J.; Li, J.; Huang, Q.S.; Yin, D.C. Protective effect of polysaccharides on simulated microgravity-induced functional inhibition of human NK cells. Carbohydr. Polym. 2014, 101, 819-827. [CrossRef]

50. Crucian, B.; Stowe, R.; Quiriarte, H.; Pierson, D.; Sams, C. Monocyte phenotype and cytokine production profiles are dysregulated by short-duration spaceflight. Aviat. Sp. Environ. Med. 2011, 82, 857-862. [CrossRef] [PubMed]

51. Thiel, C.S.; Hauschild, S.; Tauber, S.; Paulsen, K.; Raig, C.; Raem, A.; Biskup, J.; Gutewort, A.; Hürlimann, E.; Unverdorben, F.; et al. Identification of reference genes in human myelomonocytic cells for gene expression studies in altered gravity. Biomed Res. Int. 2015, 2015, 363575. [CrossRef]

52. Sapudom, J.; Mohamed, W.K.E.; Garcia-Sabaté, A.; Alatoom, A.; Karaman, S.; Mahtani, N.; Teo, J.C.M. Collagen Fibril Density Modulates Macrophage Activation and Cellular Functions during Tissue Repair. Bioengineering 2020, 7, 33. [CrossRef] [PubMed] 
53. Vogel, D.Y.S.; Glim, J.E.; Stavenuiter, A.W.D.; Breur, M.; Heijnen, P.; Amor, S.; Dijkstra, C.D.; Beelen, R.H.J. Human macrophage polarization in vitro: Maturation and activation methods compared. Immunobiology 2014, 219, 695-703. [CrossRef] [PubMed]

54. Paulsen, K.; Tauber, S.; Goelz, N.; Simmet, D.M.; Engeli, S.; Birlem, M.; Dumrese, C.; Karer, A.; Hunziker, S.; Biskup, J.; et al. Severe disruption of the cytoskeleton and immunologically relevant surface molecules in a human macrophageal cell line in microgravity-Results of an in vitro experiment on board of the Shenzhou-8 space mission. Acta Astronaut. 2014, 94, 277-292. [CrossRef]

55. Meloni, M.A.; Galleri, G.; Pani, G.; Saba, A.; Pippia, P.; Cogoli-Greuter, M. Space flight affects motility and cytoskeletal structures in human monocyte cell line J-111. Cytoskeleton 2011, 68, 125-137. [CrossRef] [PubMed]

56. Paulsen, K.; Tauber, S.; Dumrese, C.; Bradacs, G.; Simmet, D.M.; Gölz, N.; Hauschild, S.; Raig, C.; Engeli, S.; Gutewort, A.; et al. Regulation of ICAM-1 in cells of the monocyte/macrophage system in microgravity. Biomed Res. Int. 2015, 2015, 1-18. [CrossRef]

57. Tauber, S.; Lauber, B.A.; Paulsen, K.; Layer, L.E.; Lehmann, M.; Hauschild, S.; Shepherd, N.R.; Polzer, J.; Segerer, J.; Thiel, C.S.; et al. Cytoskeletal stability and metabolic alterations in primary human macrophages in long-term microgravity. PLoS ONE 2017, 12, e0175599. [CrossRef]

58. Thiel, C.S.; Tauber, S.; Lauber, B.; Polzer, J.; Seebacher, C.; Uhl, R.; Neelam, S.; Zhang, Y.; Levine, H.; Ullrich, O. Rapid Morphological and Cytoskeletal Response to Microgravity in Human Primary Macrophages. Int. J. Mol. Sci. 2019, $20,2402$. [CrossRef]

59. Wang, C.; Luo, H.; Zhu, L.; Yang, F.; Chu, Z.; Tian, H.; Feng, M.; Zhao, Y.; Shang, P. Microgravity inhibition of lipopolysaccharideinduced tumor necrosis factor- $\alpha$ expression in macrophage cells. Inflamm. Res. 2014, 63, 91-98. [CrossRef]

60. Wang, C.; Chen, H.; Luo, H.; Zhu, L.; Zhao, Y.; Tian, H.; Wang, R.; Shang, P.; Zhao, Y. Microgravity activates p38 MAPK-C/EBP $\beta$ pathway to regulate the expression of arginase and inflammatory cytokines in macrophages. Inflamm. Res. 2015, 64, 303-311. [CrossRef] [PubMed]

61. Brungs, S.; Kolanus, W.; Hemmersbach, R. Syk phosphorylation-A gravisensitive step in macrophage signalling. Cell Commun. Signal. 2015, 13, 9. [CrossRef] [PubMed]

62. Crucian, B.; Stowe, R.P.; Mehta, S.; Quiriarte, H.; Pierson, D.; Sams, C. Alterations in adaptive immunity persist during long-duration spaceflight. Jpn. Microgravity 2015, 1, 15013. [CrossRef] [PubMed]

63. Thiel, C.S.; De Zélicourt, D.; Tauber, S.; Adrian, A.; Franz, M.; Simmet, D.M.; Schoppmann, K.; Hauschild, S.; Krammer, S.; Christen, M.; et al. Rapid adaptation to microgravity in mammalian macrophage cells. Sci. Rep. 2017, 7, 2266. [CrossRef] [PubMed]

64. Stanley, A.; Thompson, K.; Hynes, A.; Brakebusch, C.; Quondamatteo, F. NADPH Oxidase Complex-Derived Reactive Oxygen Species, the Actin Cytoskeleton, and Rho GTPases in Cell Migration. Antioxid. Redox Signal. 2014, 20, 2026-2042. [CrossRef] [PubMed]

65. Shi, L.; Tian, H.; Wang, P.; Li, L.; Zhang, Z.; Zhang, J.; Zhao, Y. Spaceflight and simulated microgravity suppresses macrophage development via altered RAS/ERK/NFKB and metabolic pathways. Cell. Mol. Immunol. 2020, 18, 1489-1502. [CrossRef] [PubMed]

66. Wang, J.; Han, C.; Lu, Z.; Ge, P.; Cui, Y.; Zhao, D.; Yang, X.; Wu, B.; Qiang, L.; Zhang, Y.; et al. Simulated microgravity suppresses MAPK pathway-mediated innate immune response to bacterial infection and induces gut microbiota dysbiosis. FASEB J. 2020, 34, 14631-14644. [CrossRef] [PubMed]

67. Chapuis, F.; Rosenzwajg, M.; Yagello, M.; Ekman, M.; Biberfeld, P.; Gluckman, J.C. Differentiation of human dendritic cells from monocytes in vitro. Eur. J. Immunol. 1997, 27, 431-441. [CrossRef]

68. Tang-Huau, T.L.; Gueguen, P.; Goudot, C.; Durand, M.; Bohec, M.; Baulande, S.; Pasquier, B.; Amigorena, S.; Segura, E. Human in vivo-generated monocyte-derived dendritic cells and macrophages cross-present antigens through a vacuolar pathway. Nat. Commun. 2018, 9, 2570. [CrossRef]

69. Sapudom, J.; Alatoom, A.; Mohamed, W.K.E.; Garcia-Sabaté, A.; McBain, I.; Nasser, R.A.; Teo, J.C.M. Dendritic cell immune potency on 2D and in 3D collagen matrices. Biomater. Sci. 2020, 8, 5106-5120. [CrossRef] [PubMed]

70. Santini, S.M. A New Type I IFN-Mediated Pathway for the Rapid Differentiation of Monocytes into Highly Active Dendritic Cells. Stem Cells 2003, 21, 357-362. [CrossRef] [PubMed]

71. Qu, C.; Brinck-Jensen, N.S.; Zang, M.; Chen, K. Monocyte-derived dendritic cells: Targets as potent antigen-presenting cells for the design of vaccines against infectious diseases. Int. J. Infect. Dis. 2014, 19, 1-5. [CrossRef] [PubMed]

72. Tackett, N.; Bradley, J.H.; Moore, E.K.; Baker, S.H.; Minter, S.L.; DiGiacinto, B.; Arnold, J.P.; Gregg, R.K. Prolonged exposure to simulated microgravity diminishes dendritic cell immunogenicity. Sci. Rep. 2019, 9, 1-13. [CrossRef]

73. Low, E.K.; Brudvik, E.; Kuhlman, B.; Wilson, P.F.; Almeida-Porada, G.; Porada, C.D. Microgravity Impairs DNA Damage Repair in Human Hematopoietic Stem/Progenitor Cells and Inhibits Their Differentiation into Dendritic Cells. Stem Cells Dev. 2018, 27, 1257-1267. [CrossRef]

74. Seder, R.A.; Ahmed, R. Similarities and differences in CD4+ and CD8+ effector and memory T cell generation. Nat. Immunol. 2003, 4, 835-842. [CrossRef]

75. Weyand, C.M.; Goronzy, J.J. The immunology of rheumatoid arthritis. Nat. Immunol. 2021, 22, 10-18. [CrossRef]

76. Geenen, V. The thymus and the science of self. Semin. Immunopathol. 2021, 43, 5-14. [CrossRef] [PubMed]

77. Gensous, N.; Boizard-Moracchini, A.; Lazaro, E.; Richez, C.; Blanco, P. Update on the cellular pathogenesis of lupus. Curr. Opin. Rheumatol. 2021, 33, 190-196. [CrossRef] [PubMed] 
78. Comi, G.; Bar-Or, A.; Lassmann, H.; Uccelli, A.; Hartung, H.P.; Montalban, X.; Sørensen, P.S.; Hohlfeld, R.; Hauser, S.L. Role of B Cells in Multiple Sclerosis and Related Disorders. Ann. Neurol. 2021, 89, 13-23. [CrossRef] [PubMed]

79. Ran, Z.; Yue-Bei, L.; Qiu-Ming, Z.; Huan, Y. Regulatory B Cells and Its Role in Central Nervous System Inflammatory Demyelinating Diseases. Front. Immunol. 2020, 11, 1-18. [CrossRef] [PubMed]

80. Cogoli, A.; Tschopp, A.; Fuchs-Bislin, P. Cell sensitivity to gravity. Science 1984, 225, 228-230. [CrossRef]

81. Schwarzenberg, M.; Pippia, P.; Meloni, M.A.; Cossu, G.; Cogoli-Greuter, M.; Cogoli, A. Signal transduction in T lymphocytes-A comparison of the data from space, the free fall machine and the random positioning machine. Adv. Sp. Res. 1999, 24, 793-800. [CrossRef]

82. Hashemi, B.B.; Penkala, J.E.; Vens, C.; Huls, H.; Cubbage, M.; Sams, C.F. T cell activation responses are differentially regulated during clinorotation and in spaceflight. FASEB J. 1999, 13, 2071-2082. [CrossRef] [PubMed]

83. Cooper, D.; Pellis, N.R. Suppressed PHA activation of T lymphocytes in simulated microgravity is restored by direct activation of protein kinase C. J. Leukoc. Biol. 1998, 63, 550-562. [CrossRef]

84. Simons, D.M.; Gardner, E.M.; Lelkes, P.I. Sub-mitogenic phorbol myristate acetate co-stimulation rescues the PHA-induced activation of both naïve and memory T cells cultured in the rotating-wall vessel bioreactor. Cell Biol. Int. 2009, 33, 882-886. [CrossRef]

85. Simons, D.M.; Gardner, E.M.; Lelkes, P.I. Intact T cell receptor signaling by CD4+ T cells cultured in the rotating wall-vessel bioreactor. J. Cell. Biochem. 2010, 109, 1201-1209. [CrossRef] [PubMed]

86. Thiel, C.S.; Paulsen, K.; Bradacs, G.; Lust, K.; Tauber, S.; Dumrese, C.; Hilliger, A.; Schoppmann, K.; Biskup, J.; Golz, N.; et al. Rapid alterations of cell cycle control proteins in human T lymphocytes in microgravity. Cell Commun. Signal. 2012, 10, 1. [CrossRef] [PubMed]

87. Chang, T.T.; Walther, I.; Li, C.-F.; Boonyaratanakornkit, J.; Galleri, G.; Meloni, M.A.; Pippia, P.; Cogoli, A.; Hughes-Fulford, M. The Rel/NF-kB pathway and transcription of immediate early genes in T cell activation are inhibited by microgravity. J. Leukoc. Biol. 2012, 92, 1133-1145. [CrossRef] [PubMed]

88. Tauber, S.; Hauschild, S.; Crescio, C.; Secchi, C.; Paulsen, K.; Pantaleo, A.; Saba, A.; Buttron, I.; Thiel, C.S.; Cogoli, A.; et al. Signal transduction in primary human T lymphocytes in altered gravity-Results of the MASER-12 suborbital space flight mission. Cell Commun. Signal. 2013, 11, 32. [CrossRef]

89. Tauber, S.; Hauschild, S.; Paulsen, K.; Gutewort, A.; Raig, C.; Hürlimann, E.; Biskup, J.; Philpot, C.; Lier, H.; Engelmann, F.; et al. Signal transduction in primary human T lymphocytes in altered gravity during parabolic flight and clinostat experiments. Cell. Physiol. Biochem. 2015, 35, 1034-1051. [CrossRef]

90. Luo, H.; Wang, C.; Feng, M.; Zhao, Y. Microgravity inhibits resting T cell immunity in an exposure time-dependent manner. Int. J. Med. Sci. 2013, 11, 87-96. [CrossRef]

91. Kumarswamy, R.; Volkmann, I.; Thum, T. Regulation and function of miRNA-21 in health and disease. RNA Biol. 2011, 8, 706-713. [CrossRef]

92. Hughes-Fulford, M.; Chang, T.T.; Martinez, E.M.; Li, C.F. Spaceflight alters expression of microRNA during T-cell activation. FASEB J. 2015, 29, 4893-4900. [CrossRef]

93. Thiel, C.S.; Hauschild, S.; Huge, A.; Tauber, S.; Lauber, B.A.; Polzer, J.; Paulsen, K.; Lier, H.; Engelmann, F.; Schmitz, B.; et al. Dynamic gene expression response to altered gravity in human T cells. Sci. Rep. 2017, 7, 5204. [CrossRef]

94. Thiel, C.S.; Huge, A.; Hauschild, S.; Tauber, S.; Lauber, B.A.; Polzer, J.; Paulsen, K.; Lier, H.; Engelmann, F.; Schmitz, B.; et al. Stability of gene expression in human T cells in different gravity environments is clustered in chromosomal region $11 \mathrm{p} 15.4$. $n p j$ Microgravity 2017, 3, 22. [CrossRef]

95. Thiel, C.S.; Christoffel, S.; Tauber, S.; Vahlensieck, C.; de Zélicourt, D.; Layer, L.E.; Lauber, B.; Polzer, J.; Ullrich, O. Rapid cellular perception of gravitational forces in human Jurkat $\mathrm{T}$ cells and transduction into gene expression regulation. Int. J. Mol. Sci. 2020, 21, 514. [CrossRef]

96. Martinez, E.M.; Yoshida, M.C.; Candelario, T.L.T.; Hughes-Fulford, M. Spaceflight and simulated microgravity cause a significant reduction of key gene expression in early T-cell activation. Am. J. Physiol. Integr. Comp. Physiol. 2015, 308, R480-R488. [CrossRef]

97. Leung, S.; Smith, D.; Myc, A.; Morry, J.; Baker, J.R. OT-II TCR transgenic mice fail to produce anti-ovalbumin antibodies upon vaccination. Cell. Immunol. 2013, 282, 79-84. [CrossRef]

98. Chang, T.T.; Spurlock, S.M.; Candelario, T.L.T.; Grenon, S.M.; Hughes-Fulford, M. Spaceflight impairs antigen-specific tolerance induction in vivo and increases inflammatory cytokines. FASEB J. 2015, 29, 4122-4132. [CrossRef]

99. Bradley, J.H.; Stein, R.; Randolph, B.; Molina, E.; Arnold, J.P.; Gregg, R.K. T cell resistance to activation by dendritic cells requires long-term culture in simulated microgravity. Life Sci. Sp. Res. 2017, 15, 55-61. [CrossRef] [PubMed]

100. Bradley, J.H.; Barwick, S.; Horn, G.Q.; Ullrich, E.; Best, B.; Arnold, J.P.; Gregg, R.K. Simulated microgravity-mediated reversion of murine lymphoma immune evasion. Sci. Rep. 2019, 9, 14623. [CrossRef]

101. Morabito, C.; Lanuti, P.; Caprara, G.A.; Marchisio, M.; Bizzarri, M.; Guarnieri, S.; Mariggiò, M.A. Physiological responses of jurkat lymphocytes to simulated microgravity conditions. Int. J. Mol. Sci. 2019, 20, 1892. [CrossRef] [PubMed]

102. Vogel, J.; Thiel, C.S.; Tauber, S.; Stockmann, C.; Gassmann, M.; Ullrich, O. Expression of hypoxia-inducible factor $1 \alpha($ Hif- $1 \alpha)$ and genes of related pathways in altered gravity. Int. J. Mol. Sci. 2019, 20, 436. [CrossRef]

103. Spielmann, G.; Agha, N.; Kunz, H.; Simpson, R.J.; Crucian, B.; Mehta, S.; Laughlin, M.; Campbell, J. B cell homeostasis is maintained during long-duration spaceflight. J. Appl. Physiol. 2019, 126, 469-476. [CrossRef] 
104. Tascher, G.; Gerbaix, M.; Maes, P.; Chazarin, B.; Ghislin, S.; Antropova, E.; Vassilieva, G.; Ouzren-Zarhloul, N.; Gauquelin-Koch, G.; Vico, L.; et al. Analysis of femurs from mice embarked on board BION-M1 biosatellite reveals a decrease in immune cell development, including B cells, after 1 wk of recovery on Earth. FASEB J. 2019, 33, 3772-3783. [CrossRef] [PubMed]

105. Dang, B.; Yang, Y.; Zhang, E.; Li, W.; Mi, X.; Meng, Y.; Yan, S.; Wang, Z.; Wei, W.; Shao, C.; et al. Simulated microgravity increases heavy ion radiation-induced apoptosis in human B lymphoblasts. Life Sci. 2014, 97, 123-128. [CrossRef] [PubMed]

106. Martinac, B. Mechanosensitive ion channels: Molecules of mechanotransduction. J. Cell Sci. 2004, 117, 2449-2460. [CrossRef]

107. Zhong, M.; Komarova, Y.; Rehman, J.; Malik, A.B. Mechanosensing Piezo channels in tissue homeostasis including their role in lungs. Pulm. Circ. 2018, 8. [CrossRef]

108. Yin, J.; Kuebler, W.M. Mechanotransduction by TRP Channels: General Concepts and Specific Role in the Vasculature. Cell Biochem. Biophys. 2010, 56, 1. [CrossRef]

109. Wang, N. Review of Cellular Mechanotransduction. J. Phys. D Appl. Phys. 2017, 50, 233002. [CrossRef]

110. Johnson, W.A. Two views of the same stimulus. Elife 2017, 6, e30191. [CrossRef]

111. Martino, F.; Perestrelo, A.R.; Vinarský, V.; Pagliari, S.; Forte, G. Cellular Mechanotransduction: From Tension to Function. Front. Physiol. 2018, 9, 824. [CrossRef]

112. Li, X.; Wang, J. Mechanical tumor microenvironment and transduction: Cytoskeleton mediates cancer cell invasion and metastasis. Int. J. Biol. Sci. 2020, 16, 2014-2028. [CrossRef]

113. Jahed, Z.; Shams, H.; Mehrbod, M.; Mofrad, M.R.K. Mechanotransduction Pathways Linking the Extracellular Matrix to the Nucleus. Int. Rev. Cell. Mol. Biol. 2014, 310, 171-220. [CrossRef]

114. Huang, H.; Kamm, R.D.; Lee, R.T. Cell mechanics and mechanotransduction: Pathways, probes, and physiology. Am. J. Physiol. Physiol. 2004, 287, C1-C11. [CrossRef] [PubMed]

115. Das, T.; Safferling, K.; Rausch, S.; Grabe, N.; Boehm, H.; Spatz, J.P. A molecular mechanotransduction pathway regulates collective migration of epithelial cells. Nat. Cell Biol. 2015, 17, 276-287. [CrossRef]

116. Peterson, J.R.; Mitchison, T.J. Small Molecules, Big Impact. Chem. Biol. 2002, 9, 1275-1285. [CrossRef]

117. Oertel, A. Involvement of myosin in intracellular motility and cytomorphogenesis in Micrasterias. Cell Biol. Int. 2003, 27, 977-986. [CrossRef]

118. Ji, Y.; Li, J.; Wei, Y.; Gao, W.; Fu, X.; Wang, Y. Substrate stiffness affects the immunosuppressive and trophic function of hMSCs via modulating cytoskeletal polymerization and tension. Biomater. Sci. 2019, 7, 5292-5300. [CrossRef]

119. ElGindi, M.; Ibrahim, I.H.; Sapudom, J.; Garcia-Sabate, A.; Teo, J.C.M. Engineered Microvessel for Cell Culture in Simulated Microgravity. Int. J. Mol. Sci. 2021, 22, 6331. [CrossRef] [PubMed]

120. Shanti, A.; Samara, B.; Abdullah, A.; Hallfors, N.; Accoto, D.; Sapudom, J.; Alatoom, A.; Teo, J.; Danti, S.; Stefanini, C. MultiCompartment 3D-Cultured Organ-on-a-Chip: Towards a Biomimetic Lymph Node for Drug Development. Pharmaceutics 2020, 12, 464. [CrossRef]

121. Court, M.; Malier, M.; Millet, A. 3D type I collagen environment leads up to a reassessment of the classification of human macrophage polarizations. Biomaterials 2019, 208, 98-109. [CrossRef]

122. Garcia-Sabaté, A.; Mohamed, W.K.E.; Sapudom, J.; Alatoom, A.; Al Safadi, L.; Teo, J.C.M. Biomimetic 3D Models for Investigating the Role of Monocytes and Macrophages in Atherosclerosis. Bioengineering 2020, 7, 113. [CrossRef]

123. Logie, C.; van Schaik, T.; Pompe, T.; Pietsch, K. Fibronectin-functionalization of 3D collagen networks supports immune tolerance and inflammation suppression in human monocyte-derived macrophages. Biomaterials 2021, 268, 120498. [CrossRef]

124. Baker, B.M.; Chen, C.S. Deconstructing the third dimension-How 3D culture microenvironments alter cellular cues. J. Cell Sci. 2012, 125, 3015-3024. [CrossRef]

125. Duval, K.; Grover, H.; Han, L.-H.; Mou, Y.; Pegoraro, A.F.; Fredberg, J.; Chen, Z. Modeling Physiological Events in 2D vs. 3D Cell Culture. Physiology 2017, 32, 266-277. [CrossRef]

126. Sapudom, J.; Nguyen, K.-T.; Martin, S.; Wippold, T.; Möller, S.; Schnabelrauch, M.; Anderegg, U.; Pompe, T. Biomimetic tissue models reveal the role of hyaluronan in melanoma proliferation and invasion. Biomater. Sci. 2020, 8, 1405-1417. [CrossRef]

127. Fang, J.Y.; Yang, Z.; Han, B. Switch of macrophage fusion competency by 3D matrices. Sci. Rep. 2020, 10, 10348. [CrossRef]

128. Sapudom, J.; Rubner, S.; Martin, S.; Pompe, T. Mimicking Tissue Boundaries by Sharp Multiparameter Matrix Interfaces. Adv. Healthc. Mater. 2016, 5, 1861-1867. [CrossRef]

129. Galarza, S.; Kim, H.; Atay, N.; Peyton, S.R.; Munson, J.M. 2D or 3D? How cell motility measurements are conserved across dimensions in vitro and translate in vivo. Bioeng. Transl. Med. 2020, 5, e10148. [CrossRef]

130. Chandrasekaran, A.; Avci, H.X.; Ochalek, A.; Rösingh, L.N.; Molnár, K.; László, L.; Bellák, T.; Téglási, A.; Pesti, K.; Mike, A.; et al. Comparison of 2D and 3D neural induction methods for the generation of neural progenitor cells from human induced pluripotent stem cells. Stem Cell Res. 2017, 25, 139-151. [CrossRef]

131. Sapudom, J.; Pompe, T. Biomimetic tumor microenvironments based on collagen matrices. Biomater. Sci. 2018, 6, 2009-2024. [CrossRef]

132. Jensen, C.; Teng, Y. Is It Time to Start Transitioning From 2D to 3D Cell Culture? Front. Mol. Biosci. 2020, 7, 33. [CrossRef]

133. Ravi, M.; Paramesh, V.; Kaviya, S.R.; Anuradha, E.; Solomon, F.D.P. 3D Cell Culture Systems: Advantages and Applications. J. Cell. Physiol. 2015, 230, 16-26. [CrossRef]

134. Nicolas, J.; Magli, S.; Rabbachin, L.; Sampaolesi, S.; Nicotra, F.; Russo, L. 3D Extracellular Matrix Mimics: Fundamental Concepts and Role of Materials Chemistry to Influence Stem Cell Fate. Biomacromolecules 2020, 21, 1968-1994. [CrossRef] [PubMed] 
135. Nakamura, K.; Kuga, H.; Morisaki, T.; Baba, E.; Sato, N.; Mizumoto, K.; Sueishi, K.; Tanaka, M.; Katano, M. Simulated Microgravity Culture System for a 3-D Carcinoma Tissue Model. Biotechniques 2002, 33, 1068-1076. [CrossRef]

136. Tang, Y.; Xu, Y.; Xiao, Z.; Zhao, Y.; Li, J.; Han, S.; Chen, L.; Dai, B.; Wang, L.; Chen, B.; et al. The combination of three-dimensional and rotary cell culture system promotes the proliferation and maintains the differentiation potential of rat BMSCs. Sci. Rep. 2017, 7, 192. [CrossRef] [PubMed]

137. Zheng, H.; Tian, W.; Yan, H.; Yue, L.; Zhang, Y.; Han, F.; Chen, X.; Li, Y. Rotary culture promotes the proliferation of MCF-7 cells encapsulated in three-dimensional collagen-alginate hydrogels via activation of the ERK1/2-MAPK pathway. Biomed. Mater. 2012, 7, 015003. [CrossRef]

138. Ansorge, M.; Sapudom, J.; Chkolnikov, M.; Wilde, M.; Anderegg, U.; Möller, S.; Schnabelrauch, M.; Pompe, T. Mimicking Paracrine TGF $\beta 1$ Signals during Myofibroblast Differentiation in 3D Collagen Networks. Sci. Rep. 2017, 7, 5664. [CrossRef] [PubMed]

139. Sapudom, J.; Wu, X.; Chkolnikov, M.; Ansorge, M.; Anderegg, U.; Pompe, T. Fibroblast fate regulation by time dependent TGF- $\beta 1$ and IL-10 stimulation in biomimetic 3D matrices. Biomater. Sci. 2017, 5, 1858-1867. [CrossRef] [PubMed]

140. Hallfors, N.; Shanti, A.; Sapudom, J.; Teo, J.; Petroianu, G.; Lee, S.; Planelles, L.; Stefanini, C. Multi-Compartment LymphNode-on-a-Chip Enables Measurement of Immune Cell Motility in Response to Drugs. Bioengineering 2021, 8, 19. [CrossRef] [PubMed]

141. Ma, C.; Witkowski, M.T.; Harris, J.; Dolgalev, I.; Sreeram, S.; Qian, W.; Tong, J.; Chen, X.; Aifantis, I.; Chen, W. Leukemia-on-a-chip: Dissecting the chemoresistance mechanisms in B cell acute lymphoblastic leukemia bone marrow niche. Sci. Adv. 2020,6, eaba5536. [CrossRef]

142. Yuan, M.; Liu, H.; Zhou, S.; Zhou, X.; Huang, Y.; Hou, F.; Jiang, W. Integrative Analysis of Regulatory Module Reveals Associations of Microgravity with Dysfunctions of Multi-body Systems and Tumorigenesis. Int. J. Mol. Sci. 2020, 21, 7585. [CrossRef] [PubMed]

143. Nassef, M.Z.; Melnik, D.; Kopp, S.; Sahana, J.; Infanger, M.; Lützenberg, R.; Relja, B.; Wehland, M.; Grimm, D.; Krüger, M. Breast Cancer Cells in Microgravity: New Aspects for Cancer Research. Int. J. Mol. Sci. 2020, 21, 7345. [CrossRef]

144. Fukazawa, T.; Tanimoto, K.; Shrestha, L.; Imura, T.; Takahashi, S.; Sueda, T.; Hirohashi, N.; Hiyama, E.; Yuge, L. Simulated microgravity enhances CDDP-induced apoptosis signal via p53-independent mechanisms in cancer cells. PLoS ONE 2019, 14, e0219363. [CrossRef] [PubMed]

145. Braddock, M. From Target Identification to Drug Development in Space: Using the Microgravity Assist. Curr. Drug Discov. Technol. 2020, 17, 45-56. [CrossRef]

146. Schmidt, M.A.; Schmidt, C.M.; Hubbard, R.M.; Mason, C.E. Why Personalized Medicine Is the Frontier of Medicine and Performance for Humans in Space. New Space 2020, 8, 63-76. [CrossRef]

147. Sapudom, J.; Waschke, J.; Franke, K.; Hlawitschka, M.; Pompe, T. Quantitative label-free single cell tracking in 3D biomimetic matrices. Sci. Rep. 2017, 7, 14135. [CrossRef]

148. Scherf, N.; Franke, K.; Glauche, I.; Kurth, I.; Bornhäuser, M.; Werner, C.; Pompe, T.; Roeder, I. On the symmetry of siblings: Automated single-cell tracking to quantify the behavior of hematopoietic stem cells in a biomimetic setup. Exp. Hematol. 2012, 40, 119-130.e9. [CrossRef]

149. Pearson, Y.E.; Lund, A.W.; Lin, A.W.H.; Ng, C.P.; Alsuwaidi, A.; Azzeh, S.; Gater, D.L.; Teo, J.C.M. Non-invasive single-cell biomechanical analysis using live-imaging datasets. J. Cell Sci. 2016, 129, 3351-3364. [CrossRef]

150. Kräter, M.; Sapudom, J.; Bilz, N.; Pompe, T.; Guck, J.; Claus, C. Alterations in Cell Mechanics by Actin Cytoskeletal Changes Correlate with Strain-Specific Rubella Virus Phenotypes for Cell Migration and Induction of Apoptosis. Cells 2018, 7, 136. [CrossRef]

151. Lühr, J.J.; Alex, N.; Amon, L.; Kräter, M.; Kubánková, M.; Sezgin, E.; Lehmann, C.H.K.; Heger, L.; Heidkamp, G.F.; Smith, A.-S.; et al. Maturation of Monocyte-Derived DCs Leads to Increased Cellular Stiffness, Higher Membrane Fluidity, and Changed Lipid Composition. Front. Immunol. 2020, 11, 2908. [CrossRef] [PubMed]

152. Menachery, A.; Sapudom, J.; Vembadi, A.; Alatoom, A.; Teo, J.; Qasaimeh, M.A. Dielectrophoretic characterization of dendritic cell deformability upon maturation. Biotechniques 2021, 70, 29-36. [CrossRef]

153. Alatoom, A.; Sapudom, J.; Soni, P.; Mohamed, W.K.E.; Garcia-Sabaté, A.; Teo, J. Artificial Biosystem for Modulation of Interactions between Antigen-Presenting Cells and T Cells. Adv. Biosyst. 2020, 4, 2000039. [CrossRef]

154. Blumenthal, D.; Chandra, V.; Avery, L.; Burkhardt, J.K. Mouse T cell priming is enhanced by maturation-dependent stiffening of the dendritic cell cortex. Elife 2020, 9, e55995. [CrossRef] [PubMed]

155. Corydon, T.J.; Kopp, S.; Wehland, M.; Braun, M.; Schütte, A.; Mayer, T.; Hülsing, T.; Oltmann, H.; Schmitz, B.; Hemmersbach, R.; et al. Alterations of the cytoskeleton in human cells in space proved by life-cell imaging. Sci. Rep. 2016, 6, 20043. [CrossRef] [PubMed]

156. Wuest, S.L.; Richard, S.; Kopp, S.; Grimm, D.; Egli, M. Simulated Microgravity: Critical Review on the Use of Random Positioning Machines for Mammalian Cell Culture. Biomed Res. Int. 2015, 2015, 1-8. [CrossRef] [PubMed]

157. Neelam, S.; Lee, A.; Lane, M.A.; Udave, C.; Levine, H.G.; Zhang, Y. Module to Support Real-Time Microscopic Imaging of Living Organisms on Ground-Based Microgravity Analogs. Appl. Sci. 2021, 11, 3122. [CrossRef] 